\title{
90346
}

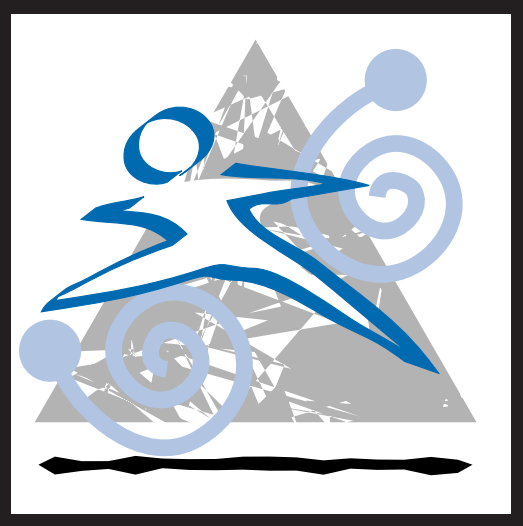

\section{Reforming the Pension Reforms: The Recent Initiatives and Actions on Pensions in Argentina and Chile}

Rafael Rofman

Eduardo Fajnzylber German Herrera

May 2008

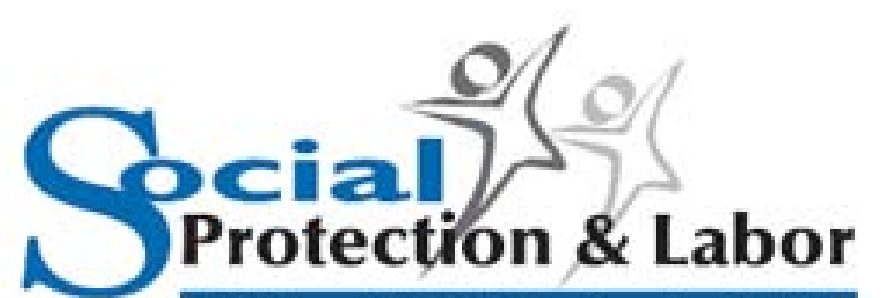
THE WORLD BAN K 


\title{
Reforming the pension reforms: The recent initiatives and actions on pensions in Argentina and Chile
}

\author{
Rafael Rofman ${ }^{1}$, Eduardo Fajnzylber ${ }^{2}$ and German Herrera ${ }^{3}$
}

May 2008

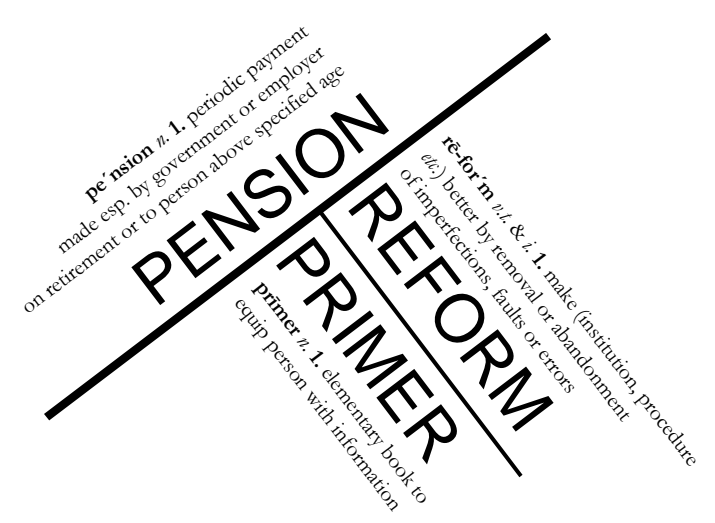

\footnotetext{
${ }^{1}$ Lead Social Protection Specialist, Latin America and the Caribbean Regional Office, The World Bank

${ }^{2}$ Head of the Research Department of the Studies Division of the Chilean. Superintendence of pension funds administrators

${ }^{3}$ Researcher, Department of Economy, University of San Andres.
}

The authors would like to thank the support of David Rabalino and the comments and suggestions of Fabio Bertranou, Carlos Grushka, Hermann von Gersdorff and an anonymous reviewer. Of course, all opinions in the document are the sole responsibility of the authors and do not represent, officially or unofficially, the views of the reviewers or their employers.

For comments or contact, rrofman@worldbank.org 


\begin{abstract}
This paper describes the recent reforms of pension policies adopted by Argentina and Chile. The structural reforms in the 1980s and 90s were targeted on improving the long term fiscal sustainability of the system and their institutional design, while transferring part of the economic and social risks from the State to participants. However, in recent years authorities in both countries coincided on identifying insufficient coverage among the elderly and adequacy of benefits as the most critical problems. As a result of differences in political economy and institutional constraints, responses were different. In Chile, a long and participatory process resulted in a large reform that focuses on impacts on the medium term, through a carefully calibrated adjustment. In Argentina, instead, reforms were adopted through a large number of successive normative corrections, with little public debate about their implications, and immediate impacts on coverage and fiscal demands.
\end{abstract}

JEL Classification: H55, J14, J26

Keywords: Argentina, Chile, pension reform, public pensions 


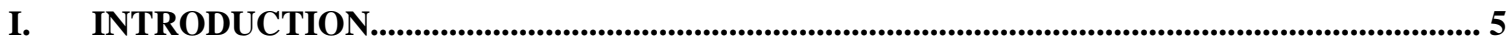

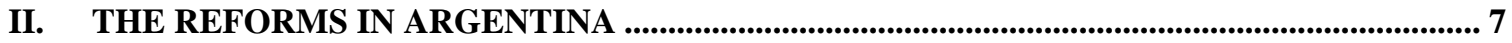

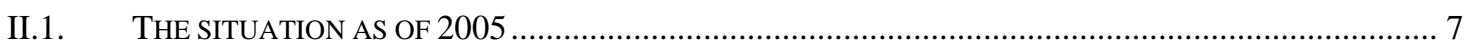

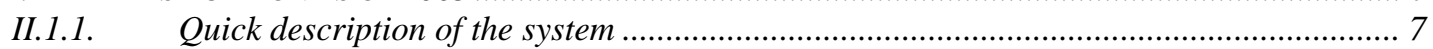

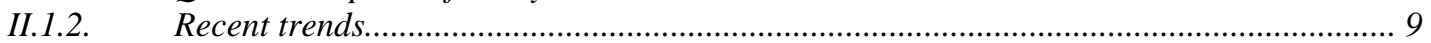

II.1.3. The political environment: Motivations for the reform.................................................... 15

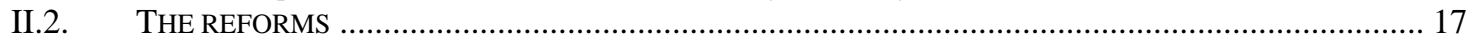

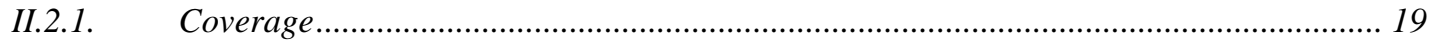

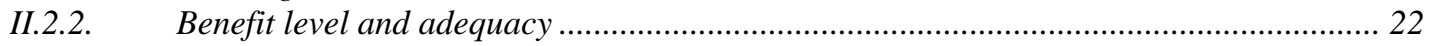

II.2.3. Administrative costs and insurance in the funded scheme ............................................ 23

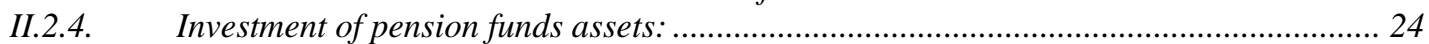

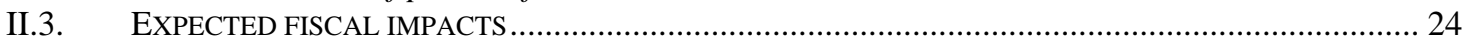

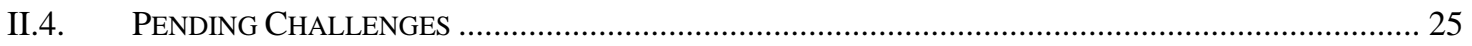

III. THE REFORMS IN CHILE ..................................................................................................... 28

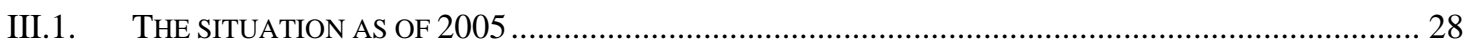

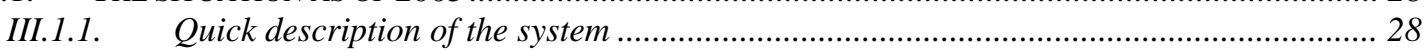

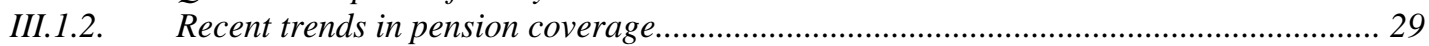

III.1.3. The political environment: Motivations for the reform...................................................... 31

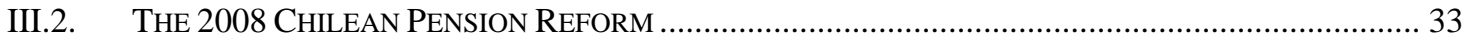

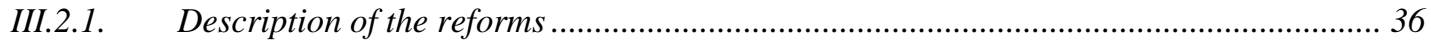

III.2.2. Expected impacts ......................................................................................................... 45

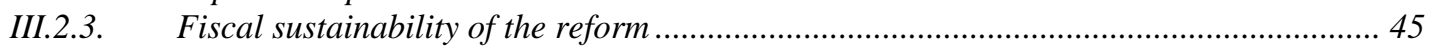

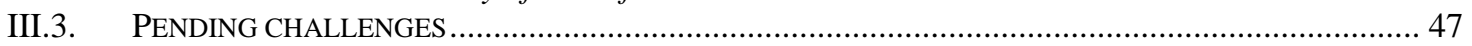

IV. INSTITUTIONS AND POLICY MAKING PROCESSES .................................................... 49

IV.1. MOTIVATIONS FOR FOCUSING ON THE POLICYMAKING PROCESSES ........................................... 49

IV.2. THE SPECIFICS OF PENSION POLICY AND ITS POLITICAL IMPLICATIONS. ......................................... 51

IV.3. A GENERAL PICTURE OF THE MAIN POLITICAL CHARACTERISTICS IN ARGENTINA AND CHILE .... 52

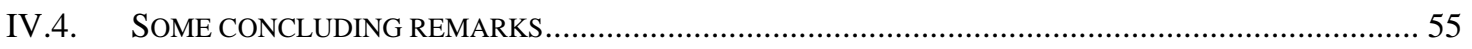

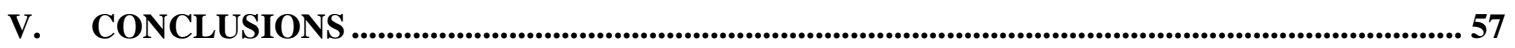

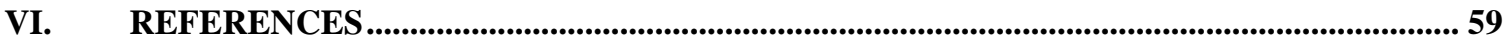


List of Figures

Figure II-1. Argentina. Pension coverage of active workers, 1992-2006 ........................ 10 Figure II-2. Argentina. Pension coverage of occupied workers, by income quintile 19922006.

Figure II-3. Argentina. Distribution of contribution densities.....

Figure II-4. Argentina. Pension coverage among the elderly (65+). Total and by income quintile 1992-2006.

Figure II-5. Argentina. Average and minimum benefits, in real terms, and percentage of beneficiaries earning the minimum 1994-2007 13 Figure II-6. Argentina. Pension expenditures, by government level, in \% of GDP 19802006.

Figure II-7. Argentina. Non contributory pensions. Beneficiaries and real value, 20012007.

Figure II-8. Argentina. National Pension System. Number of beneficiaries of pensions,

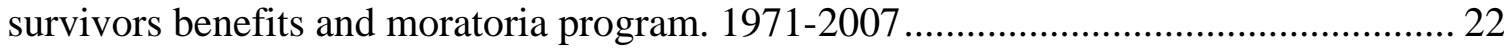

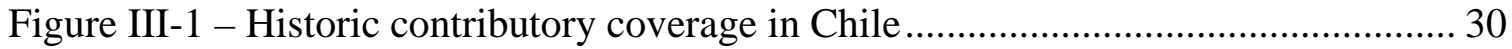

Figure III-2 - Density of contributions to the pension system ................................... 31

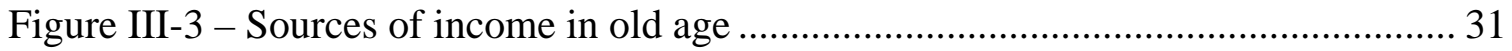

Figure III-4 - Pension projections for the Chilean pensions system (before the reform). 32

Figure III-5 - Pension related Fiscal expenditure in Chile ............................................ 33

Figure III-6 - Subsidies and final pensions under the New Solidarity Pillar .................. 37

\section{List of Tables}

Table II-1 - Main aspects of the 2005-2007 Argentina Pension Reforms ........................ 18

Table III-1 - Main aspects of the 2008 Chilean Pension Reform ................................... 34

Table III-2 - Fiscal cost of the pension reform........................................................ 46 


\section{Reforming the pension reforms: The recent initiatives and actions on pensions in Argentina and Chile}

\section{Introduction}

Argentina and Chile, two of the pioneering countries in Latin American pension reform trends of the 1980s and 1990s, have recently embarked in a new wave of revisions and adjustments of their pension systems. The motivation, process and results of these reforms are not similar, although they share some characteristics. This paper describes the most relevant components of these reforms, explaining why and how they were introduced, discussing their likely impacts and remaining challenges.

While the systems in both countries as of the early 2000s were not identical, they shared a number of characteristics. Chile was the first country in the region to introduce a structural reform to its pension system, creating a fully funded, privately managed scheme in the early 1980s. This system covered salaried workers on a compulsory basis, and independent workers could voluntarily join. While the system was designed as a defined contribution scheme, retirees had the right to receive a minimum benefit as long as they had contributed at least 20 years to the system. The minimum was financed with general revenue funds, and had a clear redistributive effect.

In Argentina, the 1993 reform introduced a similar funded scheme, although it did not fully eliminated the pay-as-you-go, defined benefit component. All workers (including independent workers) were required to participate, and their contributions would finance a multipilar scheme. At retirement, the benefit would include a defined contribution component, but also a defined benefit flat amount, that would act as a universal basic transfer received by all retirees with at least 30 years of contributions. Furthermore, Argentine workers were given the choice to opt out of the funded scheme, and continue to participate in a fully PAYG scheme. In a sense, the Argentina reform was considered at the time to be an improvement over Chile's experience. The design and approval process (Argentina's reforms went through a long debate in Congress, with many reforms introduced by Senators and Deputies, while in Chile it was introduced through a "Decree Law" approved by General Pinochet), and several aspects of the new system were thought to be better designed and more sustainable ${ }^{4}$.

Sharing some design characteristics, the systems in Argentina and Chile also had some basic problems in common. Lower than expected coverage, administrative costs that were considered too high by some analysts and authorities, too much uncertainty for participants, and equity issues were perceived as the main problems of pension systems on both sides of the Andes. Some of these problems originated in the macroeconomic and labor market performance of both countries, others from design aspects.

Many authors, analysts, and policy makers wrote and discussed about these problems in the last decade or so. While some remedial actions and small reforms were

\footnotetext{
${ }^{4}$ For example, Arenas de Mesa and Bertranou (1996) indicated that the Argentinean model has " (a)... more inter- and intragenerational solidarity; (b) relatively lower transition costs to be covered by the State; (c) higher coverage of self-employed workers; (d) a more comprehensive regulatory framework; and (d) less gender inequality"
} 
taken, deep changes were postponed, mostly due to macroeconomic and political restrictions. However, the stronger fiscal situation of both countries in recent years, and a changing political climate that brought up concerns about the effectiveness of these programs to provide adequate income security for the elderly created conditions for a new wave or reforms.

The reforms enacted in Argentina and Chile in the last couple of years recognize similar origins (the concerns about coverage, equity, and efficiency of the systems) but measures and processes were different. These differences seem to originate mostly on political and institutional disparities. In Chile, there was a strong consensus about the adequacy of the basic design of the pension system, and efforts were focused on improving it through a process that could guarantee political sustainability and fiscal predictability. In Argentina, on the other hand, the basic design of the pension system introduced in the 1990s was under strong criticism, and many of the existing problems were blamed on it. Also, the reform processes were different, possibly reflecting these differences in approach. While in Chile there was a wide public debate, with ample participation, lengthy analyses, and a slow construction of an almost universal consensus, in Argentina reforms were enacted through decrees or through laws that were briefly analyzed by Congress with little or no dissent about its contents and goals.

As a consequence of these differences, the expected results of recent reforms are also different. The paper discusses the impacts that these reforms are expected to have on coverage, benefits, fiscal accounts, and the operational and financial operation of the systems.

Interestingly, the reform processes in both countries were conducted in a relatively isolated manner from other social policy and fiscal debates. While there are many differences between the two countries, as discussed in this paper, both reforms share two clear aspects: they increased the coverage of pension systems among the elderly, at a fiscal cost. Discussions on whether increasing old age coverage was a priority for the social policies (as opposed, for example, to larger spending in education, health, or children's benefits) were mostly absent. Similarly, there was little if any debate regarding the implicit costs of these reforms in terms of requiring additional fiscal resources (that will eventually come from new taxes or reallocation of current expenditures). While these debates exceed the context of this paper, they are evidently relevant and should be considered within a wider analysis.

This paper presents a short description of the pension systems in each country as of the early 2000s, to then describe the stated motivations for reform and the main changes introduced in the systems since 2005, to finally identify some pending challenges. The fourth section discusses in more detail the political process, considering how and why differences in the political process between these two neighboring countries may result in important differences in outcomes. Finally, section five presents the conclusions. 


\section{The reforms in Argentina}

Argentina's pension system is one of the oldest in the world, as it started to develop in the early years of the twentieth century. While the first programs providing income to elderly and retirees originated in colonial times, it was only in 1905 when a large program, covering railroad workers, was created. A slow process followed this, as new occupational pension systems, usually designed as funded schemes, were introduced. In the late 1940s a strong push by the new Peronist government resulted in a quick expansion of coverage, and a few years later nearly all workers in Argentina, including salaried and self employed, were covered by relatively generous, partially funded schemes.

An important reform in the late 1960s consolidated the different schemes into three programs, and gave the National Government authority to manage them. The financial scheme was explicitly defined as a pay-as-you-go scheme, and most parameters, including contribution rates, vesting period, minimum retirement age, and replacement rates were unified. This scheme ran into financial problems as its parameters became unsustainable in a context of growing unemployment and informality, and by the late 1980s it was clear that a new reform would be necessary.

In 1993, amidst serious concerns about the medium term fiscal sustainability of the system, looking for tools to energize the local capital markets and expecting that private management would make the system more transparent and efficient, a structural reform was introduced.

In this chapter, we discuss the situation of the system as of the mid-2000s, considering the design of the system, its performance, and the social and political context. We then describe the main reforms introduced in recent times, discuss their expected impacts, and identify some of the pending challenges that authorities will confront in the future.

\section{II.1. The situation as of 2005}

\section{II.1.1. Quick description of the system}

After the 1993 reform, Argentina's pension system became a multipilar scheme, with funded and unfunded components, private and public participation in its management, and a combination of defined benefit and defined contribution model to determine the benefits paid to retirees.

The changes introduced almost 15 years ago were, by no means, a "definitive” reform. Since the original law was passed in October 1993, nearly eight hundred fifty new regulations about the pension system were approved, including thirty four laws and one hundred and thirty five decrees. While many of these norms were adopted to implement or supplement the system, there was a clear tendency to introduce short term corrections to the system.

As designed in 1993, the pension system in Argentina includes two basic pillars. First, contributions from employers (at 16 percent of salaries) would be used to finance a 
flat benefit of approximately 28 percent of average salaries to all retirees that satisfy the minimum age and vesting requirements. The second pillar would consist on a defined contribution scheme, where workers make personal contributions of 11 percent of their salaries and receive benefits after retirement.

The law established that there were two options for the second pillar. By default, workers would be enrolled in a funded scheme, managed by privately owned, commercial companies. Contributions (net of fees and insurance costs) would accumulate until retirement, when workers could get their benefit in the form of an annuity or as a scheduled withdrawal from their individual accounts. The second option was a smaller PAYG scheme, where workers would get a benefit proportional to their pre-retirement wage and the number of contributions to the new scheme. This benefit would be entirely managed by the Government' Social Security agency. Workers could chose to join this scheme when entering the labor force, and were free to switch to the funded scheme at any time, but it was not possible to move from the funded to the PAYG scheme.

In addition, a transitional benefit was established to compensate workers who had contributed to the system before the reform but would retire later. This benefit was also proportional to the pre-retirement salary and the number of years with contributions to the old system, and was subject to the same indexation rules as the other PAYG benefits.

A minimum retirement age of 65 years (60 for women) was established. Also, at least 30 years of contributions were required to receive any of the government financed benefits. These requirements meant increases of five years in minimum age and ten years in contributions, as compared to the previous law. To avoid sharp impacts on individuals close to retirement, the new minimums were to be implemented progressively, in a period of nearly 15 years after the reform.

Nearly all formal workers in Argentina were expected to participate in this new system. The three national pension schemes created in the 1960s were merged and all private workers, civil servants, and self employed would become part of this new system. Furthermore, a number of "special" regimes, designed over the year to provide a more favorable treatment to groups of workers that were supposed to be in a disadvantageous situation, were eliminated. The list of this regimes included school teachers, academic researchers, diplomats, railroad workers, judiciary employees, etcetera. Only one exception was maintained at the national level: the military and security forces, who continued to have their own, independent schemes. Also, provinces continued to manage independent systems covering provincial and municipal civil servants, and had the right to authorize the operation of occupational funds to cover some professional activities, such as lawyers, engineers, accountants, etcetera. Between 1994 and 1997 almost half the provinces transferred their systems to the national scheme, but others have continued to run their own programs to this date.

Finally, a non contributory pension system provides basic income to poor elderly. The program, originally introduced in the 1940s, offers a flat monthly transfer to individuals aged 70 and more with no other income sources. This benefit is part of a set of seven non contributory pension schemes, which also cover some poor disabled individuals, mothers with seven or more children, veterans of the Malvinas war, relatives of victims of the military dictatorship of 1976-1983, and other groups. After the 1993 
reform, these programs were formally transferred to the Social Development Secretariat, although payments continued to be managed by ANSES. The number of beneficiaries of these pensions has been limited, at around 40 thousand for old age in the late 1990s, and benefits were approximately $66 \%$ of the minimum pension ${ }^{5}$.

On the institutional design, the PAYG components would continue to be managed by the National Social Security Administration ("ANSES"), while the funded scheme would be managed by commercial firms, mostly owned by banks and insurance companies. One managing company was fully owned by the "Banco Nacion", a state owned bank, but still operated as a profit business. These companies would compete for affiliates, under a strictly regulated marketing system. They were supervised by an autonomous Superintendency, which operated under the control of the Ministry of Labor and Social Security.

\section{II.1.2. Recent trends}

After the 1993 reform, the pension system's performance in Argentina was closely linked to macro trends. On coverage, contributors slightly grew in the early years, but the declining situation in the labor market had a strong negative impact. Benefit levels for retirees were slowly growing during the 1990s, when there was no indexation of existing benefits but new beneficiaries received higher transfers, to then suffer a sharp loss in real values with the 2001-2002 crisis and start a recovery afterwards. The fiscal situation reflected the benefit trends, since the average benefit is the strongest determinant of the financial balance of the public system. Finally, the evolution of the financial situation and performance of the funded scheme evolved unevenly, with sharp changes due to the crisis and normative adjustments.

Argentina has been one of the countries in the region with highest pension coverage throughout its history. This situation began to decline as unemployment and informality grew since the 1980s. Figure II-1 shows that the percentage of the labor force covered by the system declined from over 45 percent in the early 1990s to below 40 percent by the year 2000 and then to nearly 30 percent with the crisis ${ }^{6}$. Part of this decline was caused by rising unemployment, but the impact of the weakening economic situation on compliance was also important. By considering the coverage of workers occupied (either as salaried or self employed), it becomes clear that the trend was important among them as well, since coverage declined nearly 10 percentage points during the decade. The effect was significant among those salaried (that is, excluding the self employed), showing that it affected all sectors of the economy.

\footnotetext{
${ }^{5}$ For a detailed discussion of the non contributory pension system in Argentina, see Bertranou and Grushka (2002)

${ }^{6}$ Coverage of active workers in Figure II- 1 and other parts of this paper refer to the ratio of contributors to the pension system in a given month and the labor force, occupied workers or salaried workers at the same time, as measured by a household survey.
} 
Figure II-1. Argentina. Pension coverage of active workers, 1992-2006

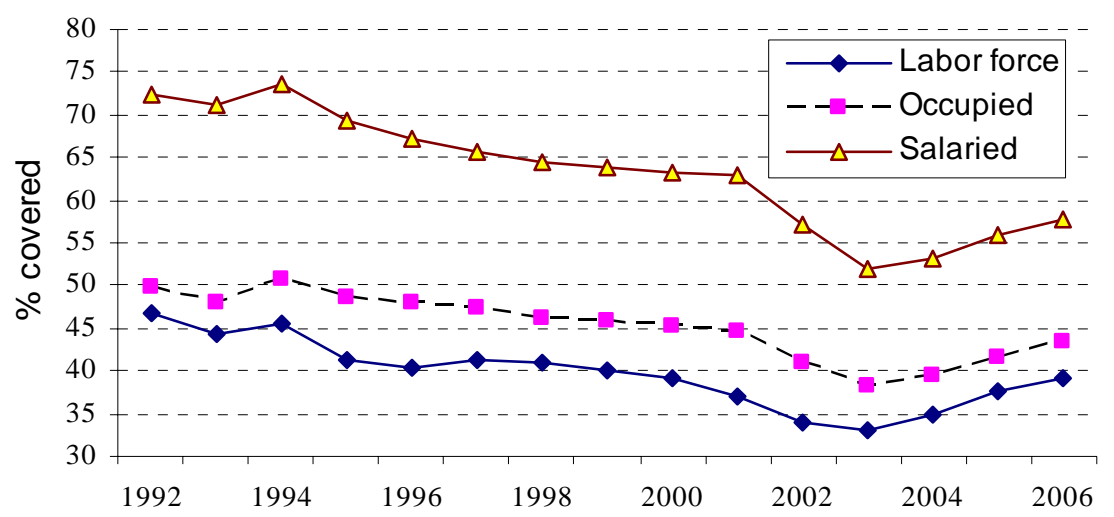

Note: Household surveys in Argentina inquire about pension coverage of salaried workers only. Thus, the coverage rate of occupied workers is somehow underestimated, as all self-employed workers appear as uncovered.

Source: Rofman and Lucchetti, 2007

Coverage began to improve after the worst of the crisis and, by 2006, the levels have recovered to those of the late1990s. However, these trends did not impact all social groups in the same way. Figure II-2 shows the evolution of coverage among occupied workers in the first quintile of income per capita and that of workers in the highest quintile. It is clear that the decline in the 1990s and even the crisis had little effect on the richest groups of the population, while, on the other hand, it was catastrophic for the poor and most vulnerable. This group showed a dramatic drop of 40 percentage points in coverage between 1992 and 2003, and the recovery since them amounted to barely five points.

Figure II-2. Argentina. Pension coverage of occupied workers, by income quintile 19922006

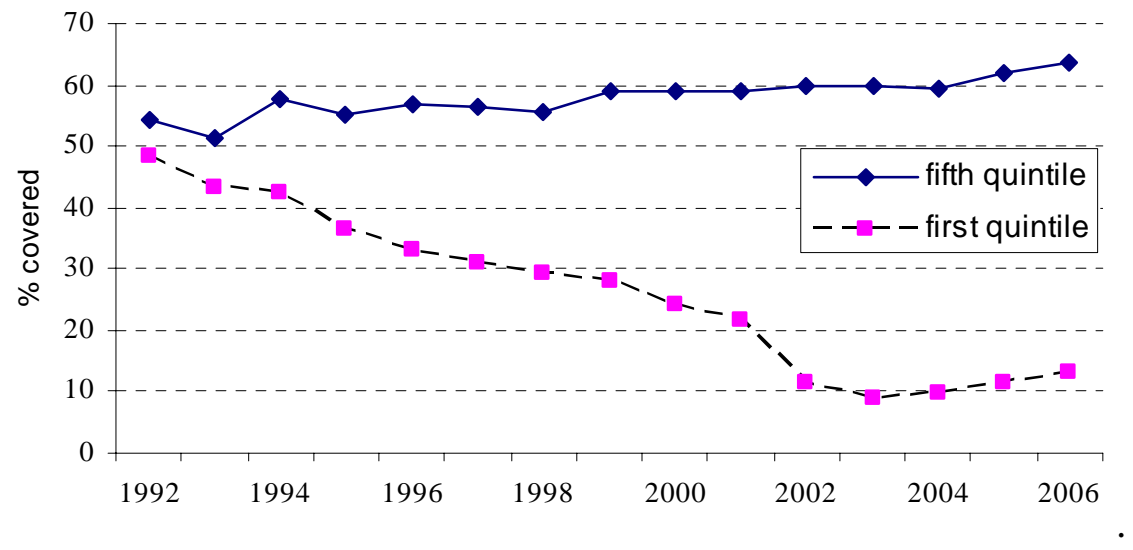

Source: Rofman and Lucchetti, 2007 
Part of the sharp decline in 2002 was caused by the introduction of the workfare program "Heads of households", which provided income transfers to nearly 2 million individuals that were previously unemployed, informal or inactive. This produced a quick growth on the labor force participation rates of the poorest groups, but did not necessarily increased their pension coverage, as the workfare participants do not contribute to the pension system.

While coverage of active workers fell during the 1990s due to unemployment and informality, this drop had a limited impact on coverage among the elderly. Due the basic design of any contributory pension scheme, changes in participation of active workers have very little effect on old age coverage in the short term, as most beneficiaries have been retired for years and many new retirees completed their vesting period long before the reforms or economic conditions changes.

As relevant as coverage in any given month, contributions densities of full career workers determine whether they will be able to retire once they reach the minimum age or not. Datasets on density are more difficult to build and analyze, as records of contributions for long periods are necessary but not always available. An analysis for Argentina was prepared by a team at the Social Security Secretariat in 2002, considering the contribution densities in the previous decade for workers with at least one contribution. Analyzing that data, the team showed that there is a wide dispersion in densities. While some workers present an almost full compliance record, many others have incomplete contribution histories, which might eventually result in their exclusion from pension benefits.

Figure II-3. Argentina. Distribution of contribution densities

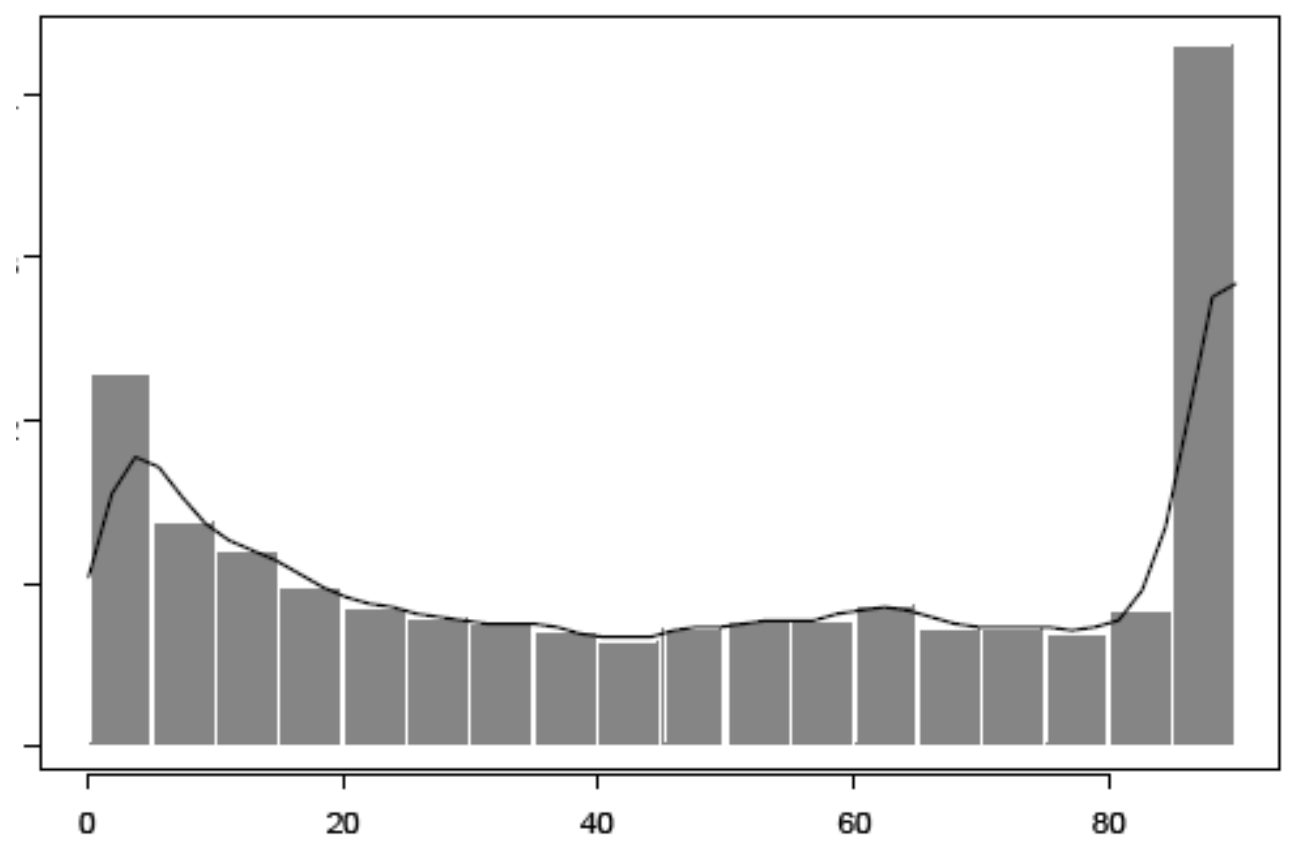

Source Farrall et al (2003) 
On the other hand, short term changes in coverage among the elderly were linked to the legislation reforms. By increasing the vesting period to 30 years, in a context of declining labor markets, the reform excluded many workers from the social security system. Administrative data from ANSES shows that the flow of new beneficiaries dramatically dropped after the reform: while in 1992-93 ANSES was granting an average of 8900 new benefits per month, five years later this figure had dropped to around 3600 cases. This decline had an impact on the total number of beneficiaries. Retirees under the national system went from 2.1 million in late 1992 to 1.6 million in 2005.

The decline in total number of retirees can be seen when considering the coverage rates of the population aged 65 and more. In 1992, there were nearly 80 beneficiaries per 100 individuals in Argentina. This figure slowly declined to 68\% by 2003. The decline was not similarly distributed across the income distribution: while retirees of the first quintile maintained coverage rates of more than 80 percent during the full period, those of the poorest group lost significant ground, going from 63\% in 1992 to twenty percentage points less by 2003. A small recovery since 2003 was probably caused by a flexibilization in access restrictions to the non contributory pensions program. Between 2003 and 2006 the number of beneficiaries of this program grew from 40 thousands to almost 90 thousand, due to the relaxation of entry restrictions ${ }^{7}$.

Figure II-4. Argentina. Pension coverage among the elderly (65+). Total and by income quintile 1992-2006

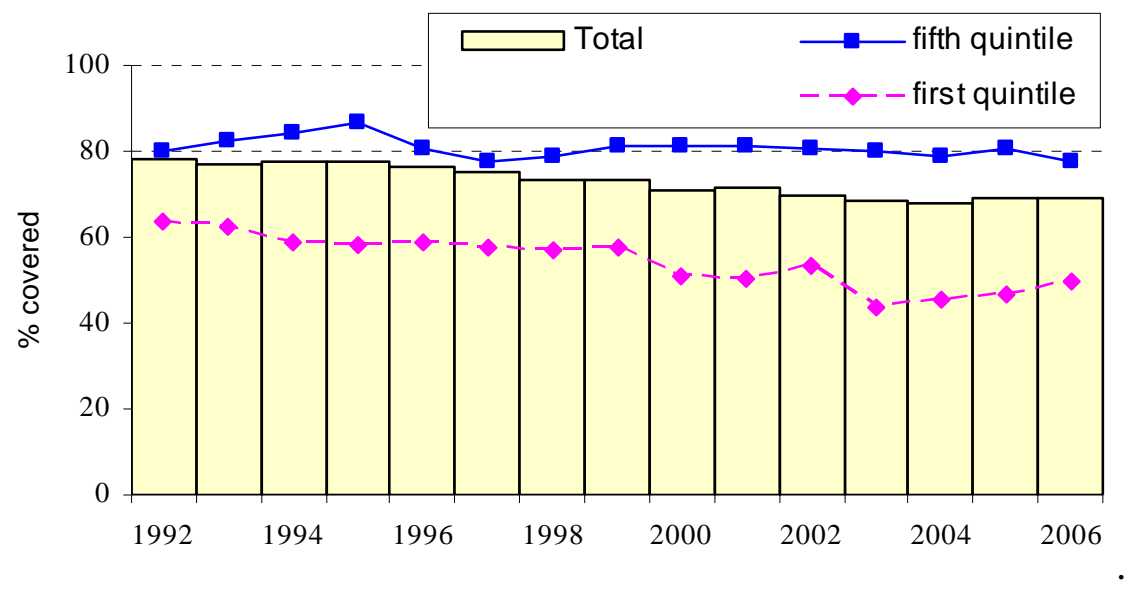

Source: Rofman and Lucchetti, 2007

While coverage of the elderly slowly declined during most of the 1990s, the value of benefits in real terms grew by more than 3.5\% per year between 1994 and the end of 2001. Interestingly, no general increases of benefits were granted during this period, but the combination of ad-hoc adjustments of individual benefits (caused by judicial decisions) and the higher level of new benefits had an important impact. On the other hand, the minimum benefit for retirees, established at $\$ 150$ in the early years of the decade, was not modified. As a result, the minimum benefit went from representing nearly 60 percent of the average in 1994 to below 50 percent in early 2002, and the

\footnotetext{
${ }^{7}$ Data from the website of Comision Nacional de Pensiones Asistenciales
} 
proportion of beneficiaries receiving the minimum benefit went from nearly 40 percent in 1994 to approximately 16 percent in $2001^{8}$.

Beginning in 2002, the Government implemented an aggressive policy to increase the minimum benefit, to compensate for inflation and also to increase its real value. After a sharp drop in 2002 due to the inflationary impact of the crisis and the peso devaluation, the minimum had recovered its previous real value by mid 2003 and, by late 2005, the real value of the minimum benefit was 60 percent higher than four years before. Meanwhile corrections for other benefits were very limited. As a consequence, by late 2005 the minimum represented 85 percent of the average benefit. This trend continued in 2006 and 2007 and, by June 2007, the ratio of the minimum to the average benefit had reached $90 \%$.

Figure II-5. Argentina. Average and minimum benefits, in real terms, and percentage of beneficiaries earning the minimum 1994-2007

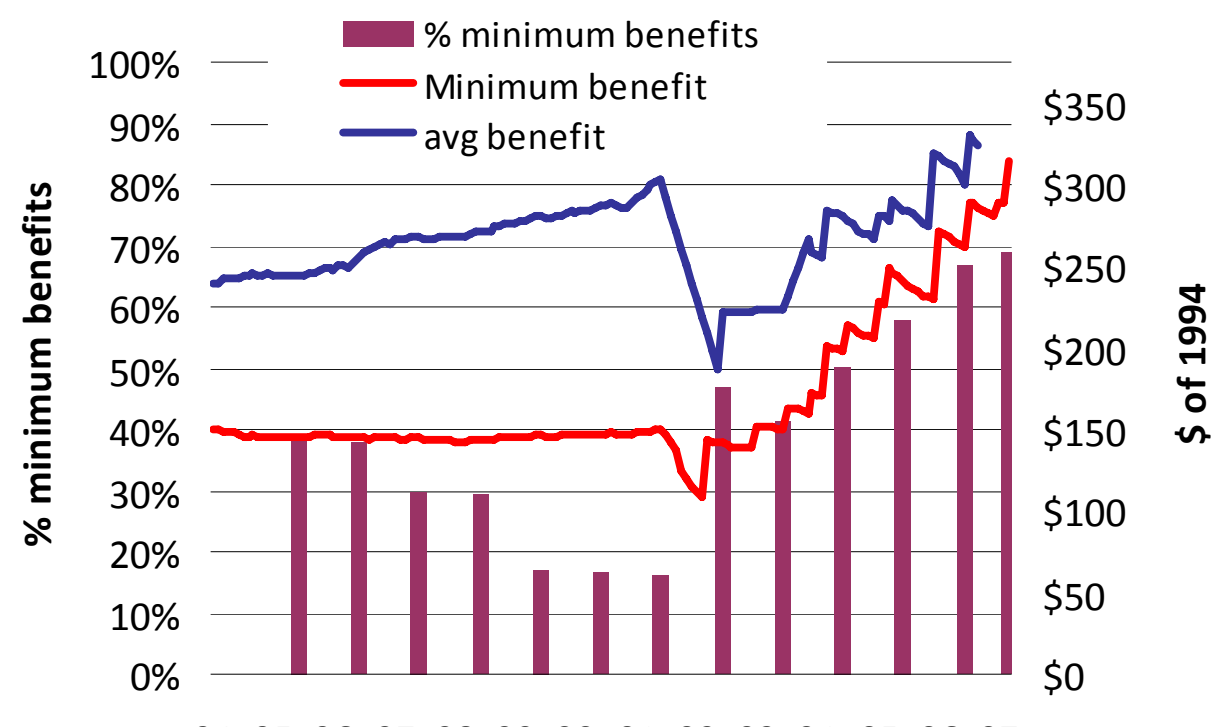

9495969798990001020304050607

Source: Moreno, 2008

The rapid increase in minimum benefits after 2002 increased the average, but many retirees have not recovered their benefits purchasing power of the 1990s. The core problem behind this has been the absence of an automatic indexation system for benefits, as all corrections are made on a discretionary basis. While Argentina's constitution indicates that pensions must be adjustable, the legislation in place since 1995 established that there would be no automatic indexation of any variable or parameter in the system. This restriction only applies to benefits from the PAYG scheme (including those of beneficiaries retired before the reform), as benefits from the funded scheme are adjusted

\footnotetext{
${ }^{8}$ Beginning in 1992, additional transfers were granted to older beneficiaries earning the minimum benefit to bring its value to $\$ 200$. The number of beneficiaries included in this provision grew during the nineties, reaching 750,000 , or nearly all beneficiaries at the minimum.
} 
through the returns of invested assets. The lack of indexation not only affects benefits of those already retired, but it also impacts benefits at retirement. The multipilar system established in 1993-94 granted benefits from several components. First, the basic, flat benefit known as "PBU" was designed to represent approximately $28 \%$ of current average wages. Since this benefit was not revised after 1995, its value has declined, especially in recent years as salaries increased. As of late 2007, PBU represented less than 15 percent of the average wages. On the other hand, benefits from the second pillar PAYG scheme (known as "PAP") and from the transitional component (known as "PC") were defined as a proportion of the "base income", the average wages of the last ten years of work before retirement. Since these wages were not indexed, an inflationary process might have an impact on them. In the early years of the new system, workers saw their base income affected by the inflation registered in 1989-1991, but these effect declined as time passed. However, the new inflationary process that began in 2002 had again an impact on these components.

Figure II-5 shows the trend in pension spending since the early 1980s. As these data come from budget accounts, it includes all pension expenditures, including non contributory, special regimes (such as the military), etcetera. The sustained growth between the mid 1980s and early 1990s explains the government efforts to introduce a reform, which had a clear impact as total spending stopped growing in 1993, and became stable at $7.5 \%-8 \%$ of GDP during most of the decade. This stability was the combined result of a growing average benefit, shown in Figure II-4, and a declining coverage, shown in Figure II-3.

The figure also shows the sharp decline in spending produced by the 2002 crisis. As average benefits suffered a drop of nearly 40 percent in that year, the slow recovery in real terms (together with the rapid growth of GDP since 2003) explain that, by 2006, total spending in pensions was still 20 percent less than before the crisis. However, expenditures at the national level presented a sharp increase in 2007, as a consequence of the recent reforms. 
Figure II-6. Argentina. Pension expenditures, by government level, in \% of GDP 19802006

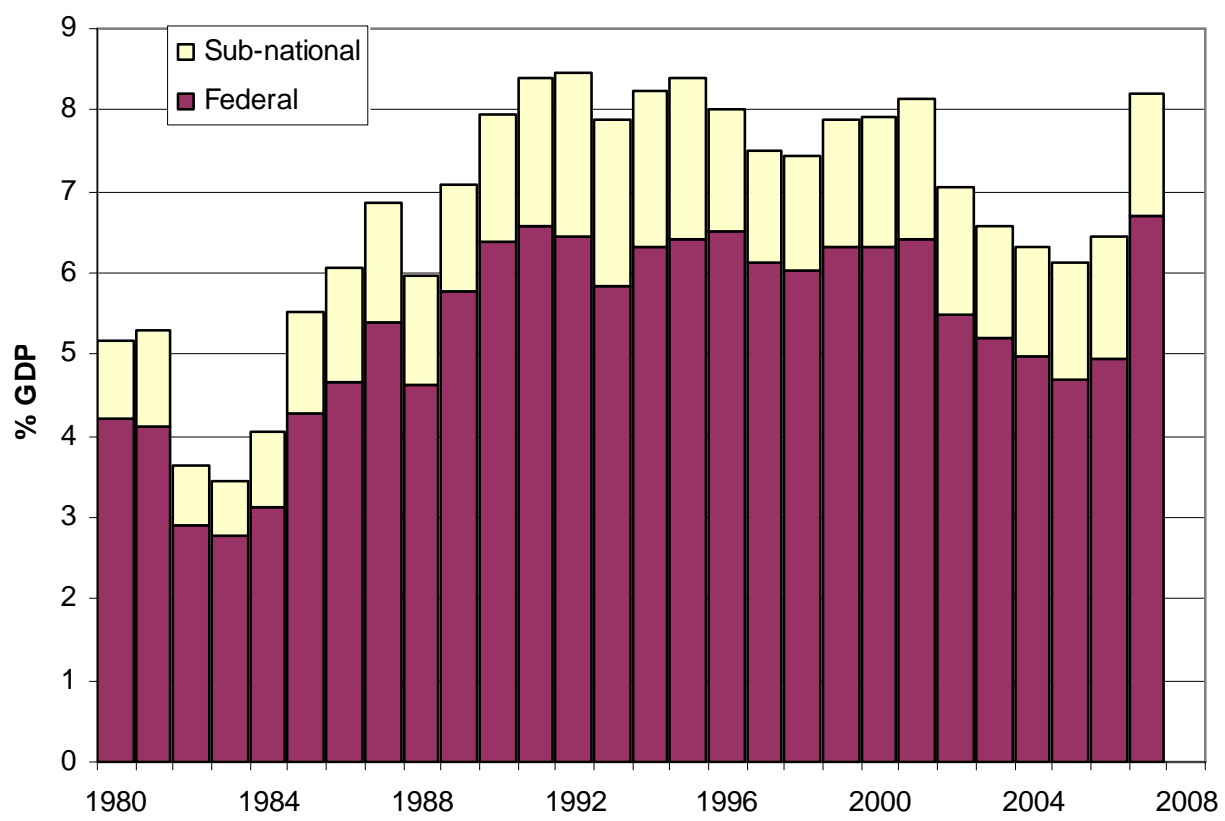

Source: MECON, 2007, and Goldschmit, 2008

\section{II.1.3. The political environment: Motivations for the reform}

Argentina' successive governments have been aware of the need to review its pension system for nearly a decade now. After the 1993 reform, authorities were not fully satisfied with the new model and pushed forward for new revisions, first through a law called "Pension solidarity law", that eliminated indexation in the system, and then through other legislation to review aspects of the funded scheme.

In 2000 a report published by the Ministry of Social Development (Secretaria de la Tercera Edad, 2000) indicated that the most critical problem of the pension system in Argentina was the declining coverage among active workers and the elderly. Later that year, a system reform that would provide coverage to elderly with less than the minimum vesting period was enacted through a decree, but never implemented.

In 2002, the Social Security Secretary organized, through a consultative process with experts, representatives of interest groups, and government officials, the preparation of a "white book" (SSS, 2002), that would define the medium term strategy for the pension policy. More public and private debates followed these efforts, and legislators introduced several pieces of draft legislation to Congress, but no action was taken.

The recent reforms in Argentina appear to have been the result of a closed-door process, where a few policymakers defined the path to follow in successive and not always coordinated steps, and little if any participation of sector authorities. At the 
normative level, there were three main actions taken since 2005 that resulted in today' system design and performance.

First, authorities decided to reinstate the special pension scheme for teachers, which had been eliminated (although this had been, in turn, successfully challenged in court). This decision was important regarding this particular group (which comprised approximately 5 percent of contributors to the system) but also as a precedent. The decree issued by the government established that the old special system for teachers, diplomats, members of the judiciary and other small groups that had been eliminated in 1994 were valid and, consequently all contributions to the funded scheme by these workers had to be transferred back to the public system.

The second, and most important, reform was enacted through a series of laws and decrees, as it resulted in a massive increase in the number of beneficiaries of the system. The legal system in Argentina allowed independent workers, since 1995, to pay contributions owed before the 1993 reform in installments, through a scheme known as “moratoria”. A new law, passed in December 2003, included in this provision contributions corresponding to the new system, and set relatively generous financial terms. Later on, as part of a law passed in December 2004 to allow some workers to apply for an early retirement scheme, it was established that independent workers applying to the "moratoria" could retire immediately, and pay the debt while receiving pension benefits. In other words, this law enacted, implicitly, a scheme to pay reduced benefits to individuals who had not contributed enough in the past. ${ }^{9}$

The institutional process that resulted in this major reform was also interesting; as the last law was a project originated in Congress, and was discussed and approved within one day, in December 16, 2004. The new law did not catch the attention of the press, or even authorities, as no public announcement of the new system was made. Only a year later, after a decree enacted in November $2005^{10}$ regulated the process the program began to operate.

Finally, by the end of January 2007 the government announced its intention to reform the pension system. On February $1^{\text {st }}$ a draft law was sent by the President to Congress and, after short discussions, it was approved on February $27^{\text {th }}$. The focus of this reform was to revise the balance between the funded and unfunded schemes in the multipilar model. The message of the Executive Branch to Congress made explicit eight goals in this reform, as an indirect way to explain its motivation. These were:

i. To improve coverage

ii. To guarantee citizen' freedom of choice between the funded and unfunded schemes

iii. To improve the equity and transparency of the system

iv. To increase the replacement rate of the system

v. To ensure a genuine financing of the system

\footnotetext{
${ }^{9}$ The three laws referred in this paragraph are 24476; 25865; and 25994.

${ }^{10}$ Decree $1454 / 2005$
} 
vi. To reduce the administrative costs of the privately managed pension funds

vii. To deepen the role of the State

viii. To guarantee a minimum benefit to all beneficiaries, without distinction between the two schemes

\section{II.2. The reforms}

If considered as a group, the reforms enacted in the pension system in Argentina in the last few years aimed at changing the system coverage and adequacy of benefits, its fiscal parameters, the role of the State and the private sector in its management and some regulations of the operational and investment regimes of the funded scheme. This section describes in more detail each of them, and indicates, when possible, the expected impacts they might have in the short and medium term. Table II-1 summarizes the main reforms, and the following subsections discuss some of their most relevant aspects. 
Table II-1 - Main aspects of the 2005-2007 Argentina Pension Reforms

\begin{tabular}{|c|c|c|}
\hline Topic & Reform & Description \\
\hline \multirow{3}{*}{$\begin{array}{l}\text { Coverage: } \\
\text { Distribution of } \\
\text { workers } \\
\text { among } \\
\text { schemes }\end{array}$} & $\begin{array}{l}\text { Special retirement } \\
\text { schemes were } \\
\text { reinstated }\end{array}$ & $\begin{array}{l}\text { Teachers, diplomats, researchers and judiciary } \\
\text { employees can retire with } 82 \% \text { of reference wages, } \\
\text { and different age or vesting periods. Their current and } \\
\text { accumulated past contributions are compulsory } \\
\text { directed to the PAYG scheme }\end{array}$ \\
\hline & $\begin{array}{l}\text { Affiliates to funded } \\
\text { scheme allowed to } \\
\text { switch back to } \\
\text { PAYG }\end{array}$ & $\begin{array}{l}\text { Workers with less than } 10 \text { years to retirement and low } \\
\text { balances in their accounts switched by default back to } \\
\text { the PAYG scheme } \\
\text { All other workers allowed to switch, once every five } \\
\text { years }\end{array}$ \\
\hline & $\begin{array}{l}\text { Default scheme } \\
\text { choice to PAYG }\end{array}$ & $\begin{array}{l}\text { New workers are enrolled by default into the PAYG } \\
\text { scheme, unless they explicitly join a pension fund. }\end{array}$ \\
\hline \multirow{3}{*}{$\begin{array}{l}\text { Coverage: } \\
\text { Elderly access }\end{array}$} & $\begin{array}{l}\text { s to Non } \\
\text { ib. Pensions }\end{array}$ & $\begin{array}{l}\text { Quotas limiting the number of Non contributory } \\
\text { pensions were eliminated. }\end{array}$ \\
\hline & & $\begin{array}{l}\text { Individuals with minimum retirement age allowed to } \\
\text { recognized debt for past contributions as self- } \\
\text { employed to complete vesting period and retire } \\
\text { immediately. }\end{array}$ \\
\hline & ent & $\begin{array}{l}\text { Individuals with less than five years to retirement age } \\
\text { and complete vesting period can retire with reduced } \\
\text { benefits (50\% of penalty, until the statutory age of } \\
\text { retirement) }\end{array}$ \\
\hline \multirow{3}{*}{$\begin{array}{l}\text { Benefit } \\
\text { level/adequacy }\end{array}$} & $\begin{array}{l}\text { dexa } \\
\text { he }\end{array}$ & to have no \\
\hline & $\begin{array}{l}\text { Discretional increases } \\
\text { with focus on the } \\
\text { minimum }\end{array}$ & $\begin{array}{l}\text { Authorities continued the policy initiated in } 2003 \text { to } \\
\text { increase the minimum benefit, and smaller increases } \\
\text { were given to other beneficiaries }\end{array}$ \\
\hline & $\begin{array}{l}\text { Benefits from new } \\
\text { PAYG scheme }\end{array}$ & $\begin{array}{l}\text { Retiring workers with contributions to the new PAYG } \\
\text { scheme will receive higher benefits (from } 0.85 \% \text { of } \\
\text { base salary per year to 1.5\%) }\end{array}$ \\
\hline \multirow{2}{*}{$\begin{array}{l}\text { Funded } \\
\text { Scheme: } \\
\text { Administrative } \\
\text { costs and } \\
\text { insurance }\end{array}$} & $\begin{array}{l}\text { Change in cost } \\
\text { definition and } \\
\text { maximum }\end{array}$ & $\begin{array}{l}\text { Pension Fund managers no longer responsible for cost } \\
\text { of disability and survivors insurance } \\
\text { Maximum administrative cost set at } 1 \% \text { of taxable } \\
\text { wage }\end{array}$ \\
\hline & $\begin{array}{l}\text { Consolidation of } \\
\text { system, pooling all } \\
\text { risks }\end{array}$ & $\begin{array}{l}\text { Elimination of insurance companies' role. New } \\
\text { scheme based on collective self-insurance of all } \\
\text { participants in pension funds }\end{array}$ \\
\hline $\begin{array}{l}\text { Investment of } \\
\text { pension funds: } \\
\text { new } \\
\text { instruments }\end{array}$ & $\begin{array}{l}\text { Investment in } \\
\text { "productive and } \\
\text { infrastructure } \\
\text { projects" allowed }\end{array}$ & $\begin{array}{l}\text { New regulation establishes that pension fund assets } \\
\text { can be invested on this new type of asset. A minimum } \\
\text { investment of } 5 \% \text { of total assets is required, departing } \\
\text { from previous practice when no minimums were used. }\end{array}$ \\
\hline
\end{tabular}

Note: Reforms in bold are part of Law 26.222. Others are the result of different regulations. 


\section{II.2.1. Coverage}

\section{II.2.1.1. Enrollment reforms for active workers}

Two aspects of the system were modified in recent times with regards to coverage. First, different groups of active workers were moved from the second pillar funded scheme to the PAYG scheme, through both voluntary and compulsory procedures. At the same time, changes in requirements to obtain a retirement benefits had an immediate impact on the number of beneficiaries, although these were temporary. On the adequacy aspect, actions (and inactions) regarding benefit levels also had an important impact.

The first element of the trend to switch contributors from the funded to the PAYG schemes was the reinstatement of special schemes for teachers, researchers, diplomats, and judiciary employees. These schemes had been eliminated by a decree in 1994, and it had been repeatedly (and successfully) challenged in court. Beginning in 2001 with the diplomats' scheme, the authorities progressively reinstated the schemes, and by March 2005 the four programs were active. In May 2007 it was decided that all workers of these schemes would have to direct their contributions to the public system. Approximately 174,000 contributors ${ }^{11}, 1.5 \%$ of the total number participating in the funded scheme, were transferred to the PAYG through this process in May $2007^{12}$.

A second group of active workers transferred to the PAYG scheme was composed by those aged more than 50 years (women) or 55 (men) with less than AR\$20,000 in their individual accounts. Law 26222 established that these workers would be switched to the PAYG scheme unless they make an explicit request to remain in a pension fund. Nearly 1.1 million affiliates were transferred through this process between July 2007 and March 2008, approximately 10 percent of the total number of affiliates (unfortunately, there is no official data available indicating how many of these were regular contributors).

Finally, the February 2007 reform also allowed all workers could switch between the schemes once every five years, opening the first period until December 2007. In those months, almost 1.3 million affiliates switched from the funded to the PAYG schemes.

These three measures implied that nearly 2.5 million affiliates, or 21 percent of the affiliates to pension funds by the end of 2006, were switched to the PAYG scheme by early 2008. Many of them may have had highly irregular contribution histories, but unfortunately there is no official data to verify how many were regular contributors.

An additional reform implemented through law 26222 was about enrolment of new workers. The original 1993 law established that new workers had to enroll in a pension fund or explicitly join the PAYG, with a default option for the funded scheme. Most workers (between 80 and 90 percent) were assigned to pension funds through this mechanism. The new law reversed the default option, and established that, unless an explicit choice is made, new workers will now be enrolled in the PAYG scheme.

\footnotetext{
${ }^{11}$ SAFJP, 2007

${ }^{12}$ While 174,000 workers were transferred in May 2007, the actual number of contributors to these programs was apparently lower, but many were transferred by mistake. The final number of workers enrolled in these special programs has not been officially reported.
} 


\section{II.2.1.2. Coverage reforms for the elderly}

Interestingly, none of the reforms that directly affect coverage of the elderly were part of the main reform law, approved in February 2007. On the other hand, it could be easily argued that this group includes the most important changes to the system. Three major reforms were implemented in recent years: (i) a relaxation of restrictions to access non contributory benefits, (ii) the "moratoria" program, that allowed many elderly with insufficient or no contributions to retire immediately, and (iii) an early retirement program.

Argentina has had non contributory benefits for many years, as part of its old age income security scheme. During most of the 1990s, these benefits were limited both in terms of access (as they were rationed and qualified applicants had to join a waiting list to receive the benefit) and adequacy. As coverage of the formal pension system among the elderly declined, the pressure to review this scheme and make it more accessible increased.

In March 2003 the National Government created the "Plan Mayores" ("Elderly Plan"), a program that, as part of the workfare scheme "Heads of Households" that was providing basic income to nearly 2 million households, would provide a basic income to individuals older than 70 years old and no other sources of income. This program began to slowly enroll beneficiaries in the poorest provinces of the country.

A few months later, in August 2003, the restriction in the number of non contributory pensions was eliminated, and new beneficiaries were admitted to the program. This resulted in a sustained increase in the number of beneficiaries, which had more than doubled by 2006. Monthly benefits were also adjusted, by 2003 they had recovered to the pre-crisis levels and, three years later, they were approximately twice the real value of 2001. 
Figure II-7. Argentina. Non contributory pensions. Beneficiaries and real value, 20012007

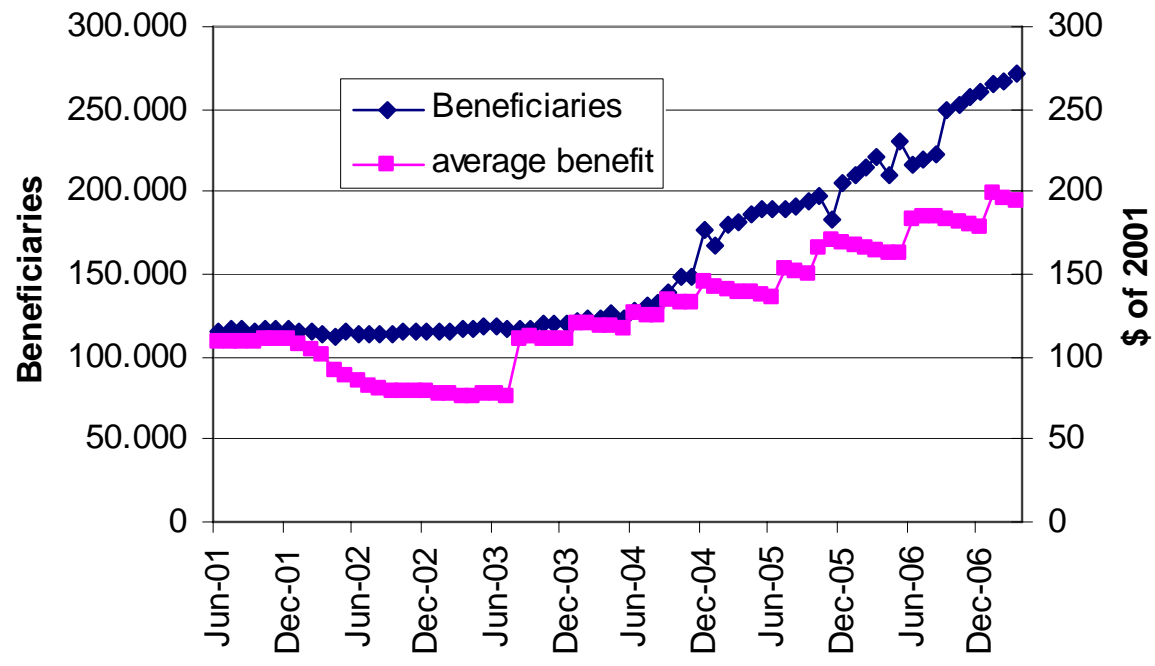

Source: ANSES, 2007

The second, in chronological order, but most important change was the introduction of the "moratoria" program. This program allowed all individuals with the minimum retirement age to apply for a benefit, after recognizing a past debt to the system. As discussed in the previous section, this program was created by a combination of successive laws and decrees, but was never formally launched or announced. While the core law of this scheme was approved in December 2004, there were barely any new benefits under this scheme until May 2007, when the number of new beneficiaries reached 50,000. After that, a rapid acceleration of the application and processing trends resulted in a total of nearly 1.7 million new beneficiaries by late 2007, a dramatic change in the long term trends. Figure II-7 shows how the number of beneficiaries of pension and survivors benefits had a rising trend since the early 1970s until the early 1990s, when the reform broke the tendency and the number began to decline. This declining trend continued until the early 2000s (with an exception in 1996-97, when beneficiaries from 10 provincial schemes were incorporated into the national scheme), but then had a sharp increase as the moratoria was implemented in 2006-2007. 
Figure II-8. Argentina. National Pension System. Number of beneficiaries of pensions, survivors benefits and moratoria program. 1971-2007

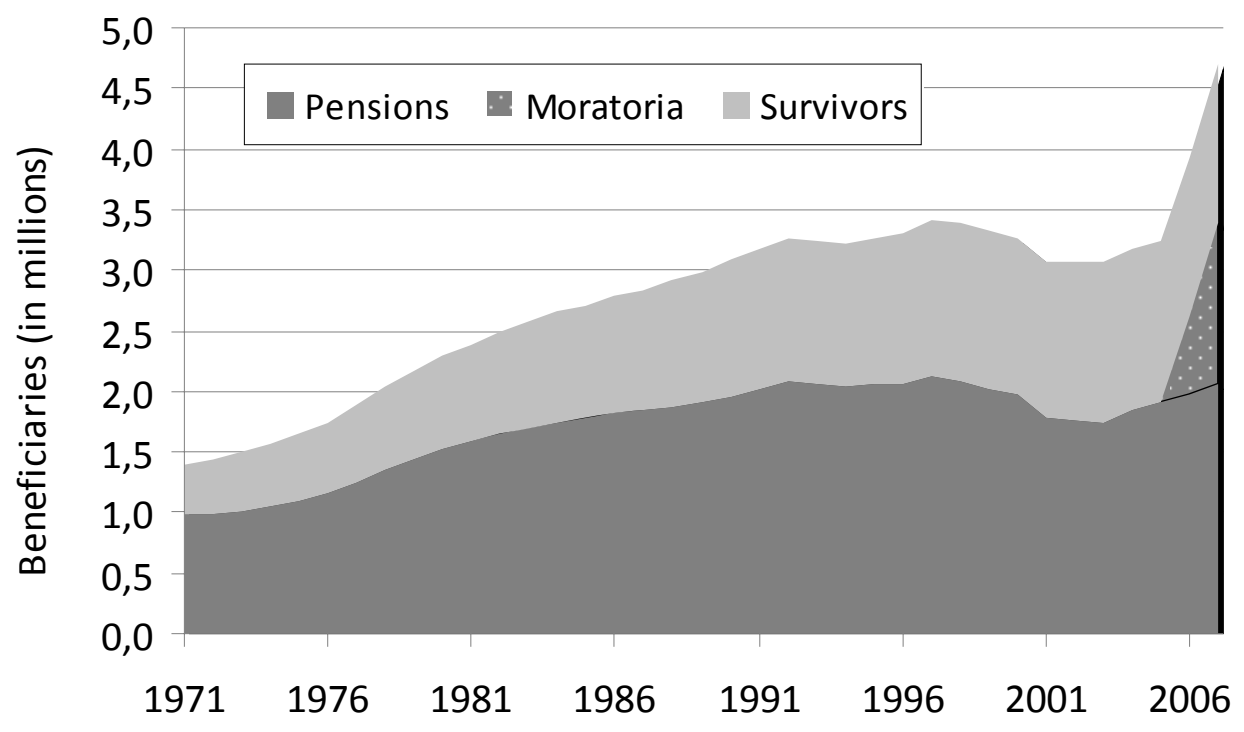

Source: Moreno, 2007

While data to assess the impact of this increase on overall old age income support coverage is not available, it is reasonable to expect that the immediate effect must have been a sharp increase in coverage. Estimating this figure is difficult, since there was no provision in the moratoria program precluding individuals already receiving a benefit (especially in the case of survivors' benefits) to apply, and an important number of duplication of benefits may have resulted from this. Citing administrative data and authors' estimations, Bodou et al (2007) indicated that total coverage of the elderly in 2007 was around 85\%, up from 69\% observed in 2006.

The third reform affecting coverage of the elderly was the introduction of an early retirement scheme, in December 2004. This program allowed workers who had reached the minimum vesting requirement, but were at most five years younger than the minimum retirement age, to retire earlier, with a reduced benefit. The program was designed to target individuals with long working careers that lost their jobs during the 2001-2002 crisis and were having problems to return to the labor force. While there is no official data available on the number of new beneficiaries under this program, an indirect estimation indicates that there should be no more than 15,000 beneficiaries under this program.

\section{II.2.2. Benefit level and adequacy}

With regards to benefit levels and adequacy, authorities implemented actions in three areas in recent years. The first action is really an "inaction", as the government decided to maintain a policy of avoiding the implementation of an automatic indexation system for beneficiaries of the PAYG scheme. The second area refers to the decisions 
taken to increase the minimum and other benefits, while the third is about changes in the expected benefits for affiliates to the PAYG scheme.

Regarding indexation, the Government has postponed decisions. As Argentina's Constitution establishes that pensions should be "mobile", thousands of lawsuit have been won by beneficiaries in the last ten years, after a 1995 reform eliminated the automatic indexation scheme. As a result of one of these lawsuits, in August 2006 the Supreme Court, in an uncommon departure from its tradition of considering each case individually, unanimously ruled that the National Government (including the Executive Branch and Congress) should define an automatic indexation system for pension benefits within a "reasonable" time. Unexpectedly, the draft law send by the Government to Congress in February 2007 (which then became Law 26.222) did not include any reference to this topic. On the other hand, the 2008 National Budget Law, approved on December 2007 established that the Executive Branch should prepare new legislation regarding the indexation of benefits, but no follow up has happened.

The main policy regarding benefit levels in recent years was the sustained increase of the minimum benefits and, more recently, some discretionary adjustments in other benefits. Figure II-4 showed how minimum benefits continued to grow, in real terms, through 2006 and 2007. By the end of this year, this benefit was four times the value corresponding to six years before, in nominal terms. Meanwhile, inflation between 2001 and 2007 was slightly over 100\%, resulting in a real increase of almost 100 percent. Other benefits were also increased, but at a much lower rate, resulting in a rapid compression of the benefits pyramid, weakening the contributory nature of the system.

Finally, several provisions in Law 26222 should result in changes of benefit levels in the future. First, the new law changed the benefits to be paid to those who chose to join the PAYG second pillar scheme -known as "PAP" for its Spanish acronym-, increasing the benefits of this component by 76 percent $^{13}$. While this change has limited effect in the short term (the PAP component of new pensioners will be small for most individuals), it could be more important in the future. Second, as workers with less than 10 years to retirement age and low balances were transferred, their expected benefits will also change. Had they stayed at the funded scheme, they would probably receive no benefit from the PAYG system, as they would never reach the minimum 30 years of contributions, and would get back, in the form of a scheduled withdrawn, their individual account balances once they reach the retirement age. As they move to the PAYG scheme, they would still not qualify for the standard benefits, nor would they get their account balances, and they will probably have to wait until they are seventy years old to apply for an old age pension.

\section{II.2.3. Administrative costs and insurance in the funded scheme}

Law 26222 defined two important changes in the way the costs of the system are accounted, financed, and charged. On one hand, the law eliminated the original 1993 provision that made pension fund managing companies responsible of paying disability

\footnotetext{
${ }^{13}$ According to the law approved in 1993 and applied until 2008, retiring workers received 0.85 percent of their base salary (the average of the last 10 years), per year of contributions to the new PAYG scheme. The new law increased this percentage to $1.5 \%$.
} 
and survivors' benefits, and required them to buy an insurance to cover these costs. Under the new scheme, a special reserve will be build with contributions from the pension funds (thus reducing the individual account balances) and benefits will be paid from these reserves. Hence, managing companies will not longer be responsible of financing them. On the other hand, a maximum administrative fee was established, at 1 percent of taxable wages. This level was slightly lower than the average registered before the reform, when the fees, net of insurance costs, were around $1.2 \%$ of taxable wages.

The reform in the insurance model eliminated the role of external insurance companies in financing survivors' and disability benefits, as the funded scheme will now self insure. The new system does not accumulate reserves. Instead, beneficiaries of disability and survivors benefits will receive a lump sum payment (which will have to be converted into an annuity or a scheduled withdrawal) from the pension fund, and adjustments across the different funds will be done on a regular basis to ensure that costs are equally supported by all participants. Benefits will continued to be paid in the form of annuities, provided by a separate set of insurance companies, or through scheduled withdrawals, paid directly by the pension funds.

\section{II.2.4. Investment of pension funds assets:}

The final area or reforms included in this discussion is the regulation of the pension fund investment portfolios. Law 24.222 created a new category of investments, called "productive and infrastructure projects". The new regulation requires a minimum investment of 5 percent of the fund in this category (a departure from previous and international practice, where there are no minimum investments) and a maximum of 20 percent. While this seems to be a minor reform, its implications could be significant in the future, depending on what type of instruments are considered as part of this new category.

\section{II.3. Expected fiscal impacts}

As a consequence of the policy making process adopted for these reforms, there have been no formal assessments of their fiscal impacts, either in the short or medium term. None of these policies was adopted citing fiscal concerns or need, nor were these concerns present in public debates or presentations. As of mid 2008, no public institution has published a document discussing the potential fiscal implications of these reforms, and public statements made by officials and policy makers have been very broad and unspecific regarding the fiscal impacts.

Among the different policies, the changes of affiliation from the funded scheme to the PAYG and the moratoria seem to be the two most relevant in fiscal terms. The changes in affiliation had an immediate impact on revenues for the public system, in the case of the workers from the special schemes and those close to retirement, as the balances of their individual accounts were transferred. This one time transfer of funds to the public system amounted to AR $\$ 8.35$ billion, nearly 20 percent of the annual expenditures in benefits by the public system. Additionally, the future flow of contributions of these workers and those who chose to switch should represent additional revenue for the public system. While it is extremely difficult to estimate the amount of 
this future flow, a simple estimation indicates that the additional annual revenue should be close to AR \$2.5 billion per year in the near future.

On the other hand, the cost of the moratoria program should be close to AR $\$ 11$ billion in the short term, although this figure should decline in the future as access to the program was closed for most workers ${ }^{14}$. The national government spent, in 2007, nearly 1.75 percentage points of GDP more than one year before, an increase that can be mostly attributed to the moratoria. For 2008, the national budget estimates that pension expenditures will be nearly twice those of 2006, in a context were prices have grown at $10-20 \%$ and GDP at $8 \%$ per year. As a result of these increases, expenditures in social security in Argentina will probably reach historical record levels in 2008, at over 9 percent of GDP.

Building a model to project medium and long term fiscal trends for the pension system in Argentina is a difficult task, mostly because several variables, such as the real value of average and minimum benefits are unknown and will be defined in a discretional way. The fiscal impact of moratoria should decline over time, as beneficiaries die, and unless new opportunities to join the program are offered in the future, its effect should tend to disappear in 15-20 years. On the other hand, the positive effect of the switch of workers should be more stable, as new workers joining the labor force will be enrolled by default in the PAYG scheme. However, benefits paid to these workers might be actuarially unbalanced, which could eventually result in negative impacts. Once again, the final outcome of this will depend on discretional decisions by the authorities.

\section{II.4. Pending Challenges}

The most critical pending challenge that the pension system has in Argentina after the recent reforms is, by far, its predictability. This problem arises from some specific issues, (first and foremost, the absence of an explicit, reliable indexation method in a country where wages have grown at 15-20 percent per year in recent years), but also from an evident weakness on the institutional processes related to the design and regulation of the system. A second core challenge is about coverage. While the "moratoria" program included most elderly in the pension system, this was supposed to be an exceptional measure, and no long term solution to the question of informality has been implemented. A third problem is the still existing fragmentation between the national system and provincial or professional schemes, and the inequities, inefficiencies and fiscal problems created by this situation. Finally, the recent reforms apparently settled some problems in the funded scheme, but may have opened other risks, and careful attention will be necessary to ensure that these risks are properly managed.

The lack of a transparent and reliable indexation scheme to adjust all variables in the system (including all PAYG benefits, minimum benefits, maximum taxable wages, reference wages, etcetera) have resulted in countless lawsuits and case-by-case responses. Furthermore, as discussed in the previous section, it is almost impossible to project future financial flows and, consequently, to consider the pros and cons of alternative policies for the medium term, limiting the space for a constructive debate on how to improve the system.

\footnotetext{
${ }^{14}$ The program remains open only for workers that can claim contributions made before 1994.
} 
Analysts and policy makers have discussed for some time about alternative approaches to define an indexation scheme. Some have proposed to link benefits to current contributors' wages, a concept that was implicit in the system originally approved in 1993. Others prefer to use the official CPI to adjust benefits, or an index built considering the consumption patterns of retirees. A different approach, more concerned with the fiscal balance of the system, has been to adjust benefits considering the evolution of revenues, in order to ensure a consistent balance through time. All these proposals have benefits and problems, in terms of methodology, and their impacts on adequacy, equity, and sustainability are potentially different. While the Supreme Court ruling has created some expectative about a possible reform to this issue, no formal decision has been taken about it.

The institutional problem is equally relevant. Formally, pension policy in Argentina is designed by the Social Security Secretariat, at the Ministry of Labor, Employment, and Social Security. However, the role of the Secretariat is diminished by the high level of autonomy of the Social Security Administration (supposedly, an executing agency), and the Superintendency of Pension Funds. Furthermore, the roles of all these institutions have been weakened by an increased centralization of the decision making process, with little inputs from the technical sectors.

The second challenge is about coverage. While no definite data is available, it was estimated that the moratoria program resulted in an increase of coverage among the elderly, which might have reached 85 percent. This improvement appears to have been achieved at a high cost, as many of the new benefits granted under the new program went to those who were already receiving a pension benefit. Still, two important questions remain. First, if this figure is correct, it is not clear whether the remaining 15 percent represent those who are relatively better-off and thus decided not to apply for benefits, or, on the contrary, they are so excluded from the system that weren't able to apply for this program. If that were the case for most of them, then it would be important to find ways to reach these individuals and include them in the system ${ }^{15}$. Second, the prevalence of high informality rates among current workers indicate that, in the future, retiring cohorts will find the same problem that those who obtained a benefit thanks to the moratoria. However, since access to this program is now limited to those who can claim contributions made before 1994, many of those currently working as informal workers will not be able to obtain a benefit in the future.

The response to this problem in the future could be to introduce new moratoria laws (although this approach would generate negative incentives for those who contribute to the pension system); to adopt a more structural approach, defining and integrated model that includes non contributory benefits for those with no contribution histories, proportional benefits for those with some contributions and full benefits for those with complete contribution records; or to simply ignore it, forcing individuals and families to find alternative income sources on their own.

\footnotetext{
${ }^{15}$ Traditionally, non contributory pensions in Argentina have been rationed and access was limited to some of those who applied for them. Thus, there is little experience in launching public effort to reach those excluded from the system.
} 
The third challenge mentioned in this section is the question of fragmentation. As defined by the Constitution, provinces have the right to set up their own pension schemes for civil servants, and to authorize the operation of occupational pension funds. While legal, the existence of multiple pension schemes in Argentina creates problems of inequities (as some provincial schemes are much more generous than the national system), and efficiency (as there are multiple problems of coordination between the different schemes). This fragmentation also has fiscal implications, because some schemes are unsustainable and require continues subsidies from provincial or national funds.

After the 1993 reform, national and provincial authorities began a process to consolidate the pension systems. Between 1994 and 1997, ten provinces transferred their schemes to the national system, thus reducing the fragmentation. However, this process was stopped at that point due to fiscal restrictions and, since then, new occupational schemes have been created throughout the country, increasing the number of independent agencies in charge of managing the programs. In this context, it is apparent that efforts to integrate the programs, either by consolidating them or introducing reforms to make the parameters of the programs consistent across jurisdictions are necessary. Also, most occupational funds are run with little or no supervision, exposing their participants (and, ultimately, the provincial and national governments) to serious financial risks.

The fourth core challenge that the pension system in Argentina will face in the near future concerns the funded pillar of the national scheme. Recent reforms introducing some interesting innovations (such as the new model of insurance of disability and survivors benefits or the promotion of investments on infrastructure instruments), but also bring challenges, as it is not clear how these innovations will perform and what type of new supervisory approach will be necessary.

Also, there are some issues that pre-exist the reforms and remain unsolved. Among those, the annuity providers market operates under conditions that are very difficult to understand for most retiring workers, who are not able to make educated choices that will affect their future income. Improved regulations and supervision, to simplify the options and ensure the adequate protection of beneficiaries are apparently necessary. 


\section{III.The reforms in Chile}

Twenty eight years after the pioneering pension reform that replaced a traditional PAYG system by one based on individual accounts, market capitalization and private management, the Chilean Congress approved in January 2008 the second largest comprehensive reform to its pension system.

In this chapter, we describe the social and political context that gave rise to this second generation reform, we provide a detailed overview of its main contents and we identify some of the pending challenges.

\section{III.1. The situation as of 2005}

\section{III.1.1. Quick description of the system}

The current Chilean pension system can be decomposed into three main pillars: a poverty prevention pillar, a contributory pillar and a voluntary pillar.

The poverty prevention pillar, before the 2008 reform, was based on two components: a means-tested assistance pension (the PASIS) and the Minimum Pension Guarantee (MPG) for individuals who contributed for at least 20 years to the individual capitalization scheme, but that were not able to finance a minimum amount for their retirement. Together, these two programs corresponded to the main government programs aimed at avoiding old age poverty, and were financed by general revenue. ${ }^{16}$

The contributory pillar was drastically reformed in 1980. The previous system was based on a number of PAYG schemes, that provided defined benefits calculated as a proportion of the wages received during the last period of working life. Theses schemes were running increasing deficits, caused by large imbalances between the benefits that were promised and the contributions that were made into the system. In 1980, the military government created a unique national scheme that was based on individual accounts where each worker's savings are deposited and invested in financial instruments by professionals firms, the Pension Fund Administrators (the AFP system). ${ }^{17}$ These firms can freely set an administrative fee in exchange for the different services they provide (collection, record-keeping, investment, benefit calculation and payment, and customer service) and individuals can switch at any time between AFPs.

Individuals are not allowed to withdraw funds from their individual accounts until they retire, which can happen at any point after the legal retirement age (65 years for men and 60 for women) or before that (early retirement) if they have accumulated enough funds in their account and they receive a minimum replacement rate. When the individual retires, he or she can choose between buying an annuity from an insurance company or receiving a programmed withdrawal stream from the AFP. In both cases, benefits are

\footnotetext{
${ }^{16}$ One could argue that there is another important component of the old-age social protection network: free and guaranteed access to the public health system. However, this is not discussed in this paper as it concentrates on the pension system.

${ }^{17}$ Only the armed forces, military and police, remained in their previous PAYG schemes.
} 
actuarially calculated as a function of the individuals savings accumulated over the lifetime, the potential beneficiaries and (age and gender-specific) life expectancy. ${ }^{18}$

To complement the compulsory savings made into the contributory scheme, tax incentives are provided for individuals who make additional voluntary savings in a special set of financial products: voluntary savings accounts managed by the AFPs, mutual funds offered by banks, insurance-plus-savings products provided by insurance companies, etc. The scheme is set so that the part of the individual's income that is allocated into these special products is exempt from income taxes during the years the deposits were made. Interest income from these savings is also tax-exempt, but pensions financed by these savings pay regular income taxes when they are received by the worker. Individuals are allowed to withdraw funds before retirement, but with a penalty, and in addition to the income taxes that ought to be paid at the time of this withdrawal.

\section{III.1.2. Recent trends in pension coverage}

As the Chilean pension system has been largely based on contributions from formal salaried workers, contributory coverage is one of the most important determinants of pension coverage. Since the early system of the 1930, between 60 and 70 percent of the labor force has been enrolled in the pension systems in Chile (Arenas de Mesa, 2000). The indicator shows some variance, depending on the economic cycles and labor markets conditions. After the 1981 reform, available data provides information about actual contributors, and not just enrolled workers. The ratio of contributors to labor force, as shown in Figure III-1, has slowly increased in the last two decades.

\footnotetext{
18 A detailed description of the current AFP system can be found in Berstein (2007), available in the English section of www.safp.cl. A number of articles have been written about the impact the 1980 Chilean pension reform may have had on social security coverage, financial development, national savings and economic performance. For instance, see Corbo \& Schmidt-Hebbel (2003), World Bank (1994), Holzmann et al (2005)
} 
Figure III-1 - Historic contributory coverage in Chile

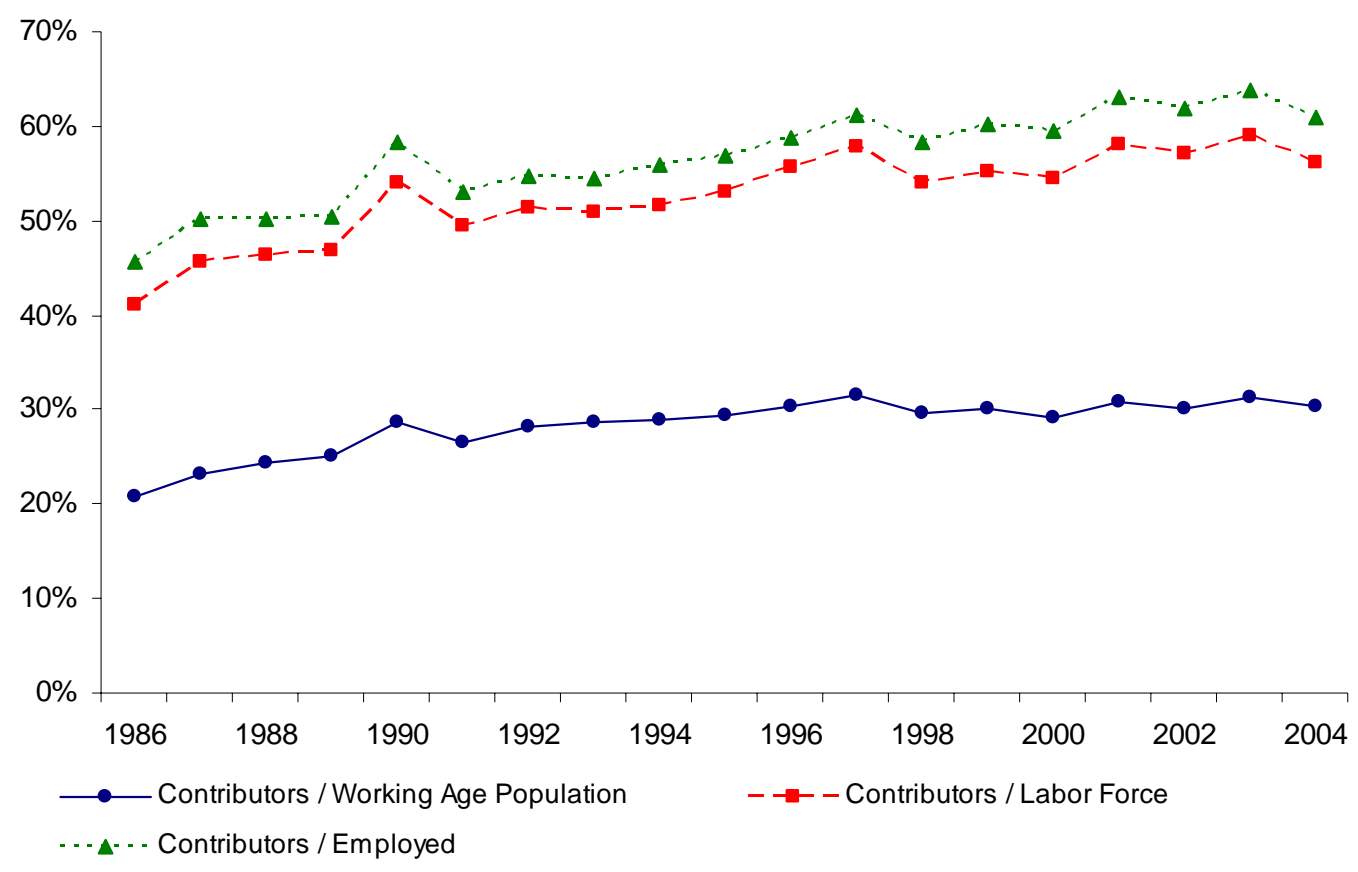

Source: Figure 1, Berstein, Larrain and Pino (2006).

It has been argued, however, that more important than contributory coverage is the density of contributions of workers, i.e. the fraction of working life during which a person makes contributions to social security. Figure III-2 presents the distribution of this measure for Chilean men and women, making evident the high degree of heterogeneity in contribution histories: from individuals who contribute all of their available time to individuals who barely contribute during their lifetime and all the possibilities in between. This heterogeneity is particularly strong among women, who show a strongly bimodal distribution, with significant mass in the two extremes (0 and 100\%) ${ }^{19}$.

\footnotetext{
${ }^{19}$ The estimation of contribution densities was prepared considering actual data for 24,000 workers, active between ages 16 and 59 .
} 
Figure III-2 - Density of contributions to the pension system

Men Women
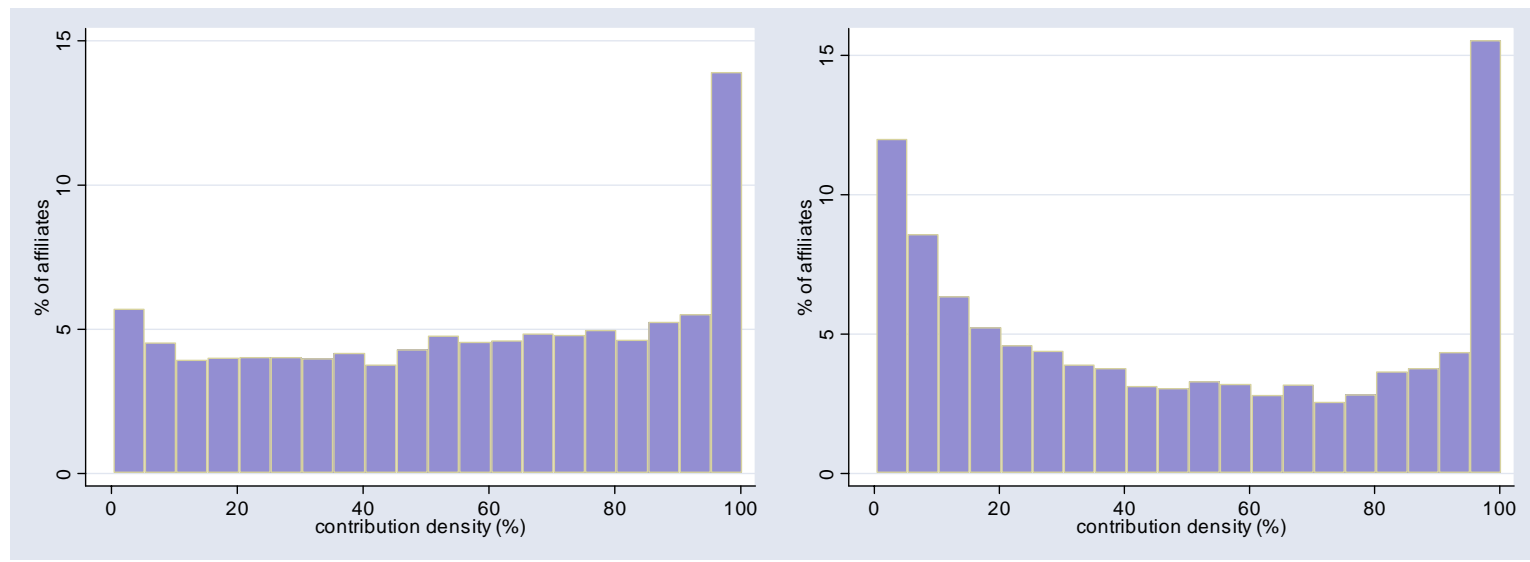

Source: Figure 2, Berstein, Larrain and Pino (2006).

Finally, Figure III-3 shows the distribution of old age coverage in the Chilean population. Approximately half of the population over 70 receives a benefit from a contributory scheme (currently, most of this coverage is provided by pensions from the PAYG regimes but their importance is decreasing every year as the AFP system matures). The bottom graph shows the different sources of income for those individuals who do not receive a direct benefit from a contributory scheme: assistance pensions, widow pensions and disability payments provide some form of coverage for close to $60 \%$ of this group.

Figure III-3 - Sources of income in old age
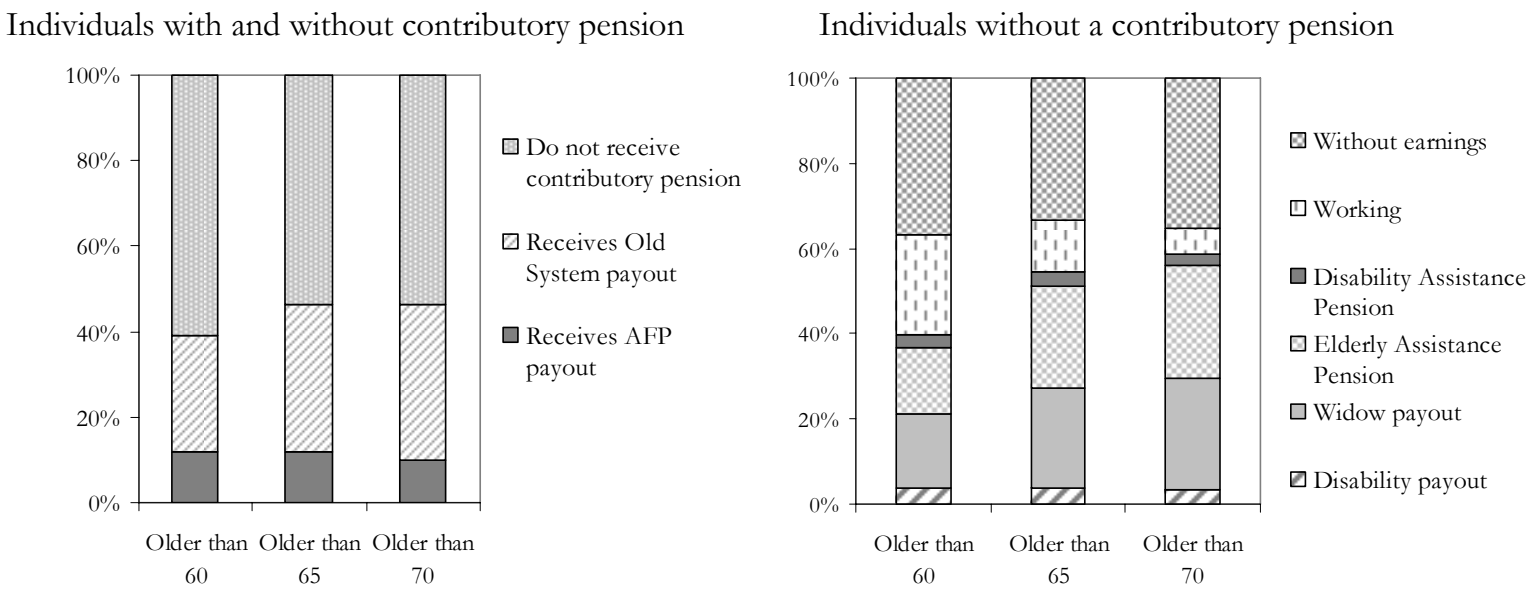

Source: Figure 5, Berstein, Larrain and Pino (2006).

\section{III.1.3. The political environment: Motivations for the reform}

A number of factors may have contributed to the adoption by presidential candidate Michelle Bachelet, of pension reform as one of the main campaign promises 
for the 2005 election. Since Chile's return to democracy, a center-left coalition had won three consecutives elections taking in each case, at least one important reform to the policies or institutions created during Pinochet's 17 year ruling period: President Aylwin's period (1990-1994) was centered on creating a stable political environment for a successful return to democracy; President Frei’s period (1994-2000) concentrated its efforts on education and infrastructure reforms and President Lagos' (2000-2006) main achievements were a reform to the private health insurance system created by Pinochet and the creation of a privately run unemployment insurance scheme based on individual accounts. Pension reform, especially a reform to the non-contributory component was clearly one of the pending debts of the governing coalition. This demand for a coverage enhancing reform was partly justified by the first coverage studies that were published in 2005 and 2006, suggesting that large fractions of the population were not going to be able to finance a minimum pension and would not qualify for the minimum pension guarantee (that required 20 years of contributions). ${ }^{20}$ Figure III-4 shows the results of one of these projections, in terms of the projected level of coverage for the affiliates to the Chilean pension system (before the current reform).

Figure III-4 - Pension projections for the Chilean pensions system (before the reform)

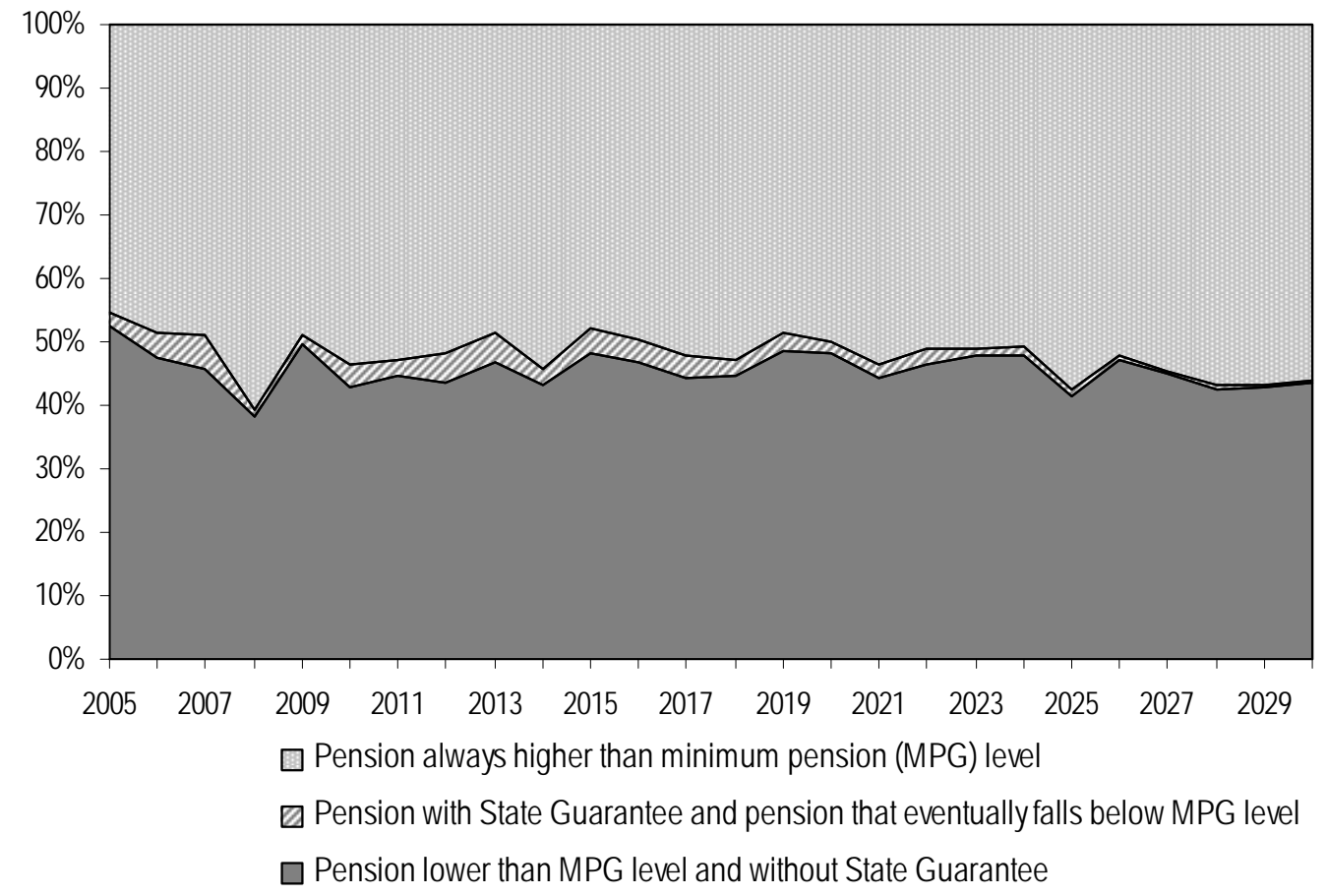

Source: Figure 7, Berstein, Larrain and Pino (2006).

A second important factor that must have been considered in the decision to undergo a strong pension reform is the fiscal space that was being created by the gradual reduction in the transition costs generated by the original pension reform of 1980. As Figure III-5 shows, both the operational deficit associated with the phased-out PAYG

\footnotetext{
${ }^{20}$ See Berstein, Larrain and Pino (2005) and Arenas de Mesa et al (2006) .
} 
system and the recognition bond obligations made to workers who switched to the new system were, by 2005, starting to decline. This represented an opportunity to introduce a broad social safety net for old age.

Figure III-5 - Pension related Fiscal expenditure in Chile

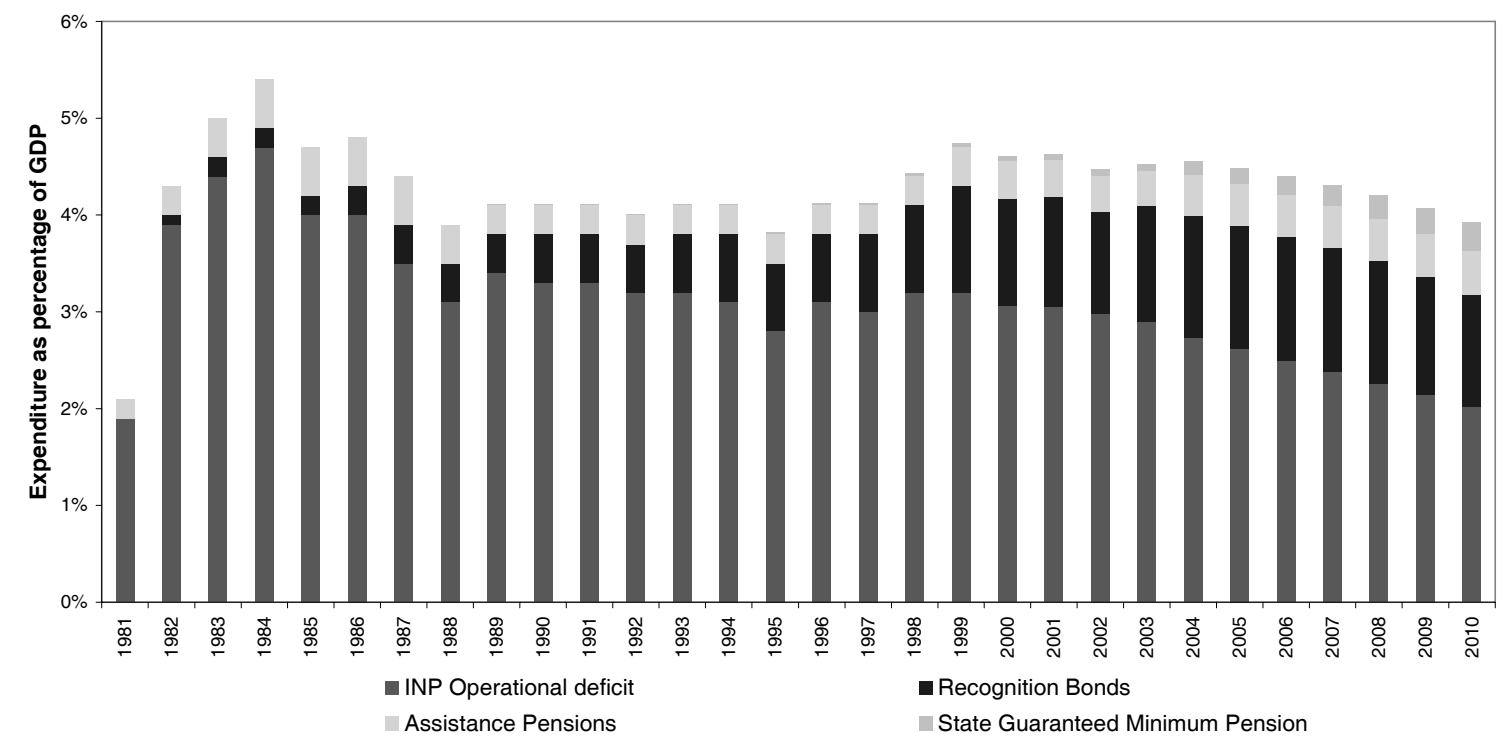

Source: ECLAC (2006).

Finally, a certain consensus was reached that the AFP industry was becoming increasingly concentrated and the combination of extraordinary profits over assets with lack of entry over a long period were symptoms that price competition was not working properly in this particular market. These were certainly some of the factors in President Bachelet's decision to take pension reform as her main contribution to the social and economic development of the country.

\section{III.2. The 2008 Chilean Pension Reform}

In March 2006, newly elected President Michelle Bachelet appointed a presidential committee of 15 professionals, experts in the different areas related to the pension system, to draw a report with reform recommendations for the pension system. ${ }^{21}$ Two years later, a comprehensive bill was approved by Congress, representing the most significant reorganization since the original 1980 reform that created the AFP pension scheme. The scheme was essentially maintained in its original form but significant improvements are introduced to increase the coverage of the poverty prevention pillar, to improve gender equality in the pension system, to intensify the scope of competition in the AFP industry, and to introduce a more flexible investment regime for the AFPs.

In this section, we review the main elements of the reform (summarized in Table III-1), its expected impacts and fiscal sustainability. We conclude the section with some of the expected challenges to be addressed in the future.

\footnotetext{
${ }^{21}$ See Consejo Asesor Presidencial para la Reforma Previsional (2006).
} 
Table III-1 - Main aspects of the 2008 Chilean Pension Reform

\begin{tabular}{|c|c|c|}
\hline Topic & Reform & Description \\
\hline $\begin{array}{l}\text { Coverage through } \\
\text { poverty- prevention } \\
\text { pillar }\end{array}$ & $\begin{array}{l}\text { Creation of a New } \\
\text { Solidarity Pillar }\end{array}$ & $\begin{array}{l}\text { * Provides a Basic Solidarity Pension (PBS) to individuals } \\
\text { with no pension earnings, belonging to the } 60 \% \text { poorest } \\
\text { individuals in the population. } \\
\text { * Provides a Pension Solidarity Complement (APS) to } \\
\text { individuals who were able to finance a small pension. }\end{array}$ \\
\hline \multirow{4}{*}{$\begin{array}{l}\text { Coverage/adequacy } \\
\text { through } \\
\text { contributory pillar }\end{array}$} & $\begin{array}{l}\text { Compulsory } \\
\text { contributions from } \\
\text { self-employed } \\
\text { workers }\end{array}$ & $\begin{array}{l}\text { * After a transition period, self employed workers in certain } \\
\text { tax categories will be required to make contributions into the } \\
\text { AFP system, through their annual income tax statement. }\end{array}$ \\
\hline & $\begin{array}{l}\text { Subsidy to } \\
\text { contributions from } \\
\text { low income young } \\
\text { workers }\end{array}$ & $\begin{array}{l}* \text { The first } 24 \text { contributions of low income workers aged } \\
\text { between } 18 \text { and } 35 \text { will be partly subsidized by the State and } \\
\text { an additional contribution will also be financed for these } \\
\text { contributions. }\end{array}$ \\
\hline & $\begin{array}{l}\text { Additional } \\
\text { contribution for } \\
\text { women }\end{array}$ & $\begin{array}{l}\text { * Women and men will be charged the same fee for the } \\
\text { disability and survivorship insurance but men have higher risk } \\
\text { rates. The difference will be deposited in women's account. }\end{array}$ \\
\hline & $\begin{array}{l}\text { Additional tools for } \\
\text { the supervision of } \\
\text { contribution } \\
\text { payment }\end{array}$ & $\begin{array}{l}\text { * Circumstances where employers stop making contributions } \\
\text { without formal reporting will be automatically considered as } \\
\text { "declared but not paid”. } \\
\text { * Employers who will be allowed } 3 \text { additional days if they } \\
\text { file contributions electronically. }\end{array}$ \\
\hline \multirow{2}{*}{$\begin{array}{l}\text { Coverage/adequacy } \\
\text { through voluntary } \\
\text { pillar }\end{array}$} & $\begin{array}{l}\text { Legal framework } \\
\text { for Collective } \\
\text { Voluntary Savings } \\
\text { Plans }\end{array}$ & $\begin{array}{l}\text { * Provides tax incentives for firms to set up collective plans } \\
\text { where workers contributions are matched, to some extent, by } \\
\text { the employer, subject to a minimum vesting period. }\end{array}$ \\
\hline & $\begin{array}{l}\text { Tax incentives for } \\
\text { middle income } \\
\text { workers }\end{array}$ & $\begin{array}{l}\text { * Allow for tax exemptions either at the time of contribution } \\
\text { or at the time of withdrawal. } \\
\text { * There is a bonus set by the State to low-income individuals } \\
\text { who make voluntary contributions on an individual or } \\
\text { collective basis }\end{array}$ \\
\hline \multirow{3}{*}{$\begin{array}{l}\text { Gender equity in the } \\
\text { pension system }\end{array}$} & $\begin{array}{l}\text { Bonus for every } \\
\text { live birth }\end{array}$ & $\begin{array}{l}\text { * The State will either deposit a bonus in the woman' account } \\
\text { or increase the amount of the PBS in the annuity-equivalent } \\
\text { for every live birth or adopted child. The amount of the bonus } \\
\text { is equivalent to } 18 \text { months of contributions at the minimum } \\
\text { wage rate, plus the average rate of return of the pension } \\
\text { system between the birth of the child and the moment the } \\
\text { woman turns } 65 \text {. }\end{array}$ \\
\hline & $\begin{array}{l}\text { Savings } \\
\text { redistribution in } \\
\text { case of divorce or } \\
\text { annulment }\end{array}$ & $\begin{array}{l}\text { * The judge can order, as a means of economic compensation, } \\
\text { to redistribute savings between the two accounts, up to } 50 \% \\
\text { of the funds that were accumulated during the period they } \\
\text { were married. }\end{array}$ \\
\hline & $\begin{array}{l}\text { Symmetric } \\
\text { treatment of men } \\
\text { and women in the } \\
\text { pension system }\end{array}$ & $\begin{array}{l}\text { * Women can now leave, in case of death, pensions to their } \\
\text { surviving spouse } \\
\text { * Separate contracts for men and women are set for the } \\
\text { disability and survivorship insurance. }\end{array}$ \\
\hline
\end{tabular}


Main aspects of the 2008 Chilean Pension Reform (cont.)

\begin{tabular}{|c|c|c|}
\hline Topic & Reform & Description \\
\hline \multirow{6}{*}{$\begin{array}{l}\text { Increase price } \\
\text { competition } \\
\text { in the AFP } \\
\text { industry }\end{array}$} & $\begin{array}{l}\text { Competitive } \\
\text { bidding for new } \\
\text { members }\end{array}$ & $\begin{array}{l}\text { The Superintendency of Pensions will set, every } 2 \text { years, a bidding process: } \\
\text { The AFP who offers the lowest fee will automatically receive all new } \\
\text { participants in the system for a period of } 24 \text { months. This fee applies to all } \\
\text { members of AFP }\end{array}$ \\
\hline & Incentives for & * AFPs are now allowed to outsource most of their functions \\
\hline & $\begin{array}{l}\text { separation of AFP } \\
\text { functions though } \\
\text { outsourcing }\end{array}$ & * Tax disadvantages of outsourcing are eliminated \\
\hline & $\begin{array}{l}\text { Separation of } \\
\text { disability and } \\
\text { survivorship } \\
\text { insurance }\end{array}$ & $\begin{array}{l}\text { All AFPs must set up, together, a bidding process to obtain disability and } \\
\text { survivorship insurance. Today, each AFP hires its own policy. }\end{array}$ \\
\hline & $\begin{array}{l}\text { Simplification of } \\
\text { fee structure }\end{array}$ & $\begin{array}{l}\text { Facilitates cost comparison by allowing only one type of fee (as a fixed } \\
\text { percentage of taxable income). }\end{array}$ \\
\hline & $\begin{array}{l}\text { New actors in the } \\
\text { industry }\end{array}$ & $\begin{array}{l}\text { * Insurance companies are allowed to create an AFP subsidiary but } \\
\text { maintaining the sole purpose nature of the regulation. }\end{array}$ \\
\hline \multirow[t]{2}{*}{$\begin{array}{l}\text { Investment } \\
\text { regime }\end{array}$} & $\begin{array}{l}\text { More flexible } \\
\text { investment limits }\end{array}$ & $\begin{array}{l}\text { * Only structural limits are fixed by law: other limits are set by secondary } \\
\text { regulation, with advice from an Investment Technical Committee. } \\
\text { * This increased flexibility is accompanied by greater responsibility from the } \\
\text { AFP, who must now set up special Board Committees for investments and } \\
\text { conflicts of interest and explicit investment policies. } \\
\text { * Eventually, investment limits may be replaced by risk measurement and } \\
\text { control. }\end{array}$ \\
\hline & $\begin{array}{l}\text { Higher limit for } \\
\text { foreign investment }\end{array}$ & $\begin{array}{l}\text { The maximum investment limit can be increased to up to } 80 \% \text { of the value of } \\
\text { the Pension Fund. The Central Bank will set it within a 30\%-80\% range. }\end{array}$ \\
\hline \multirow{3}{*}{$\begin{array}{l}\text { Participation, } \\
\text { Information } \\
\text { and education }\end{array}$} & $\begin{array}{l}\text { Creation of an AFP } \\
\text { Users' Committee }\end{array}$ & $\begin{array}{l}\text { * Representatives of workers, retirees and administrators will make } \\
\text { evaluations and propose improvements }\end{array}$ \\
\hline & $\begin{array}{l}\text { Creation of } \\
\text { Pension Education } \\
\text { Fund }\end{array}$ & $\begin{array}{l}\text { * Financed by State transfers and private donations } \\
\text { * Funds will be invested in promotion or education campaigns, selected } \\
\text { through a competitive process. }\end{array}$ \\
\hline & $\begin{array}{l}\text { Creation of } \\
\text { Pension Advisors }\end{array}$ & $\begin{array}{l}\text { * Individuals who offer independent advice on the different choices faced by } \\
\text { workers, and that are paid from the individual's fund, with a lifetime } \\
\text { maximum. }\end{array}$ \\
\hline $\begin{array}{l}\text { Social } \\
\text { security } \\
\text { institutional } \\
\text { framework }\end{array}$ & $\begin{array}{l}\text { Creation of new } \\
\text { institutions }\end{array}$ & $\begin{array}{l}\text { * The Social Security Institute is created to manage the New Solidarity Pillar } \\
\text { (NSP), as well as remaining participants in old regime. } \\
\text { * Integral Pension Assistance Centers (CAPRIs) are created throughout the } \\
\text { country to receive applications to the NSP. } \\
\text { * Superintendency of Pensions replaces the current Superintendency of } \\
\text { AFPs, with a broad oversight over private and public participants } \\
\text { * The Pension Advice Committee is created to assist the Labor and Finance } \\
\text { Ministries in issues related to the NSP. }\end{array}$ \\
\hline
\end{tabular}




\section{III.2.1. Description of the reforms}

\section{III.2.1.1. Measures to increase extension and quality of coverage in the pension system}

The individual nature of the AFP system creates a direct link between the frequency, timing and amount of the contributions made by an individual and the benefits he/she obtains. Pensions tend to be smaller when individuals face long periods without contributions, caused by occupational choices or informality, make a late entry into the formal labor market or make contributions that are not proportional to their actual income. Furthermore, actuarial calculations imply that life expectancy increases require higher savings to allow for reasonable replacement rates, either in the form of higher voluntary savings, extended working lives or reduced pension periods. The Chilean 2008 reform addresses these concerns in a number of ways: replacing the poverty prevention pillar with a strong New Solidarity Pillar, making participation compulsory for a large group of self employed workers, facilitating the creation of employer-sponsored voluntary savings plans, creating direct incentives for voluntary savings from low and middle income workers, and a number of measures that improve gender equality in the system, which will be discussed in the next section.

\section{The New Solidarity Pillar (NSP)}

Previous to the reform, poverty in old age was partially addressed by two main programs: the minimum pension guarantee, that provided a floor for pensions for individuals who contributed for at least 20 years, and the Assistance Pensions program (PASIS) for poor individuals with no pension entitlements. ${ }^{22}$

The 2008 reform replaces these programs with a unique scheme that guarantees that all individuals in the $60 \%$ less affluent fraction of the population will have a guaranteed basic pension, regardless of their contribution history. ${ }^{23}$ This new program provides old age and disability subsidies, financed by general revenues of the State.

Individuals with no contributions are entitled to an old-age Basic Solidarity Pension (PBS), once they reach 65 years of age, and fulfill the affluence and residence requirements. ${ }^{24}$ Individuals who made contributions but will receive a pension below a

\footnotetext{
${ }^{22}$ As of March 2008, the minimum pension guarantee is equivalent to US\$222 (US\$242 after age 70 and \$257 after age 75) and the PASIS program provides old age, disability or mental deficiency benefits equivalent to US\$110 before age 70, US\$117 after age 70 and US\$128 after age 75 (all US\$ figures based on an exchange rate of 435.10 pesos per dollar, existing as of March 12, 2008, the day the reform was officially promulgated). For an analysis of this poverty prevention pillar and alternative designs, see Fajnzylber (2006).

${ }^{23}$ The scheme will be introduced gradually: in the first year, beginning in July 2008, the Basic Solidarity Pension will be equivalent to US\$137 and restricted to the $40 \%$ less affluent population. This benefit will increase to approximately US $\$ 172$ in July 2009 , and cover up to the $45 \%$ poorest individuals. The final schedule of benefits will be in place in July 2012, covering up to the $60 \%$ poorest individuals.

${ }^{24}$ The affluence test is a form of means-testing applied to determine that a person does not belong to the $40 \%$ richest fraction of the population (60\% in the first year). Initial implementation ( 2 years) will be based on the Ficha de Protección Social, a means-testing instrument that calculates the vulnerability of the
} 
certain threshold are entitled to a Pension Solidarity Complement (APS), with the same affluence and residence requirements ${ }^{25}$. The disability program provides benefits under similar conditions, but for individuals between the ages of 18 and 64. Once disabled individuals reach the age of 65 , they are eligible for old-age solidarity benefits.

The schedule of subsidies is best described in Figure III-6, which presents solidarity subsidies and total pensions, as a function of self-financed entitlements.

Figure III-6 - Subsidies and final pensions under the New Solidarity Pillar

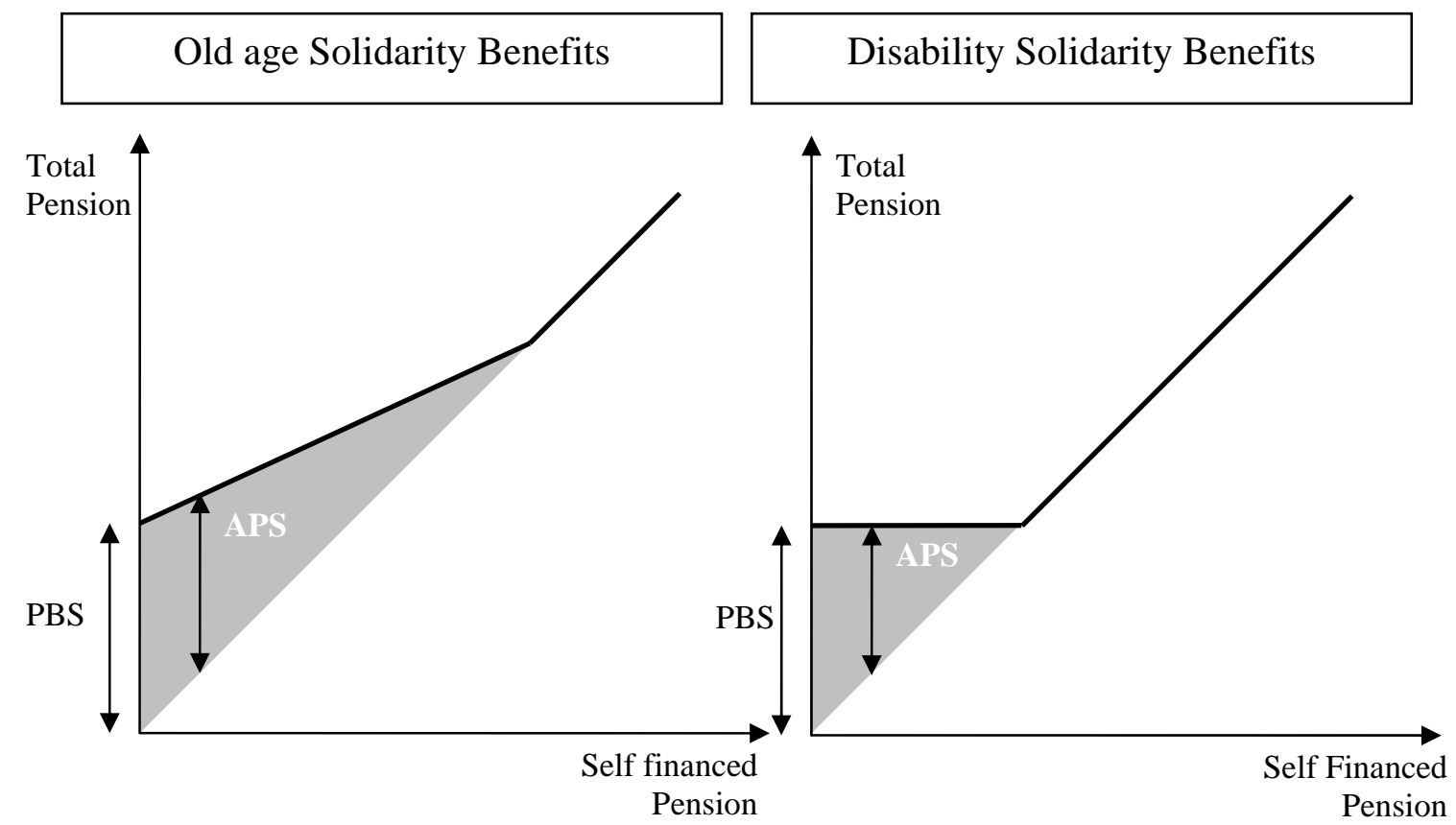

It is worth noticing two particular elements of this design: the strong integration between the contributory system and the solidarity pillar and the concern for contributory incentives that this integration raises. Integration allows guaranteeing that everybody in the first three quintiles will receive a pension equivalent to, at least, the PBS. If the benefit had been established with a cap (as in the disability case), there would be strong disincentives to contribute for low income individuals, as their retirement income would not increase with the number or amount of contributions. With the chosen design, old-age total pensions are monotonically increasing with self financed savings, i.e. every dollar saved always increases retirement income, but not by a full dollar.

members belonging to a household, based on information about their capacity to generate income, selfreported earnings, administrative data on pensions and need adjustments based on age and disability status. More information about the instrument can be found in www.fichaproteccionsocial.cl. The residence test requires that individuals must have resided in Chile for at least 20 years since the age of 20, and at least 3 in the 5 years prior to requesting the benefit.

${ }^{25}$ The Pension Solidarity Complement will be first paid to those whose contribution financed benefits are below US\$161 and belong to the poorest 40 percent of the population in July 2008, to progressively grow until 2012, when the benefit will reach those receiving less than US\$586 on contribution financed pensions and belong to the poorest 60 percent. 
This is certainly the most important component of the 2008 reform, both in terms of extension of coverage and assurance that every old person in Chile will have access to some form of protection. Current projections show that this program alone will drastically reduce income inequality in the years to come. The main challenge is, of course, the ability to develop sound fiscal policy to be able to finance the additional cost of the reform over the next decades, during which the country will be exposed to a significant increase in its demographic dependency ratio. This challenge will be partially compensated by the gradual reduction in the fiscal pressure generated by the transition from the PAYG system to the AFP scheme. Since the 1980 reform, the government has been financing the fiscal deficits generated by the previous regime (deprived of most of its contribution revenue) and the obligations contracted with the workers who switched to the new system. These obligations are now starting to phase-out leaving fiscal space to finance the new pillar.

\section{Compulsory contributions from self-employed workers}

Benefits from the New Solidarity Pillar will be paid to eligible individuals, regardless of the reason that originated the lack of contributions. In particular, selfemployed workers are not required to make social security contributions for their old age. Consistent with the extension of coverage brought by the introduction of the NSP, the reform requires all self employed workers who receive income subject to income tax to make social security contributions on their annual earnings. ${ }^{26}$ The introduction of this requirement will be gradual, starting with an information period of 3 years, followed by a period of 3 years during which workers will be required to make contribution unless explicit manifestation not to do so (the default option will be to participate in the system). During this interim period, the fraction of taxable earnings subject to this requirement will be increased, from $40 \%$ during the first year, to $70 \%$ during the second and to $100 \%$ during the third year. Starting in 2015, compulsory participation will be fully implemented.

The main challenge involved in this reform will be the ability of authorities to enforce its application. Experience in other countries in the region has shown that self employed workers tend to have much lower level of compliance than wage earners. While the situation in Chile seems to be better than in neighboring countries (as shown by the high levels of compliance with income tax regulations), this will still be a difficult process. On the other side, this component of the reform is only targeted to self-employed workers subject to regular income tax regulations, leaving outside most informal sectors of the economy: agricultural workers and fishermen, small-scale producers and retailers, etc.

\footnotetext{
${ }^{26}$ More precisely, these workers will have to contribute approximately $12.5 \%$ (10\% savings plus $2.5 \%$ corresponding to administrative fees and the disability and insurance premium) of their annual taxable earnings. Taxable earnings for self employed workers are equivalent to $80 \%$ of the annual earnings received under that status. There is a minimum contribution amount equivalent to the contribution rate applied to one minimum salary, and a maximum level, equivalent to the contribution rate applied to the maximum taxable earnings for social security that applies to dependent workers. This new requirement also includes making contributions to a public or private health insurance program.
} 


\section{Collective Voluntary Savings Plans (APVC) and incentives for low and middle income workers}

As in many other countries, voluntary savings for old age can benefit from tax exemptions in Chile. This type of savings is known as a Voluntary Pension Savings plan (in Spanish, an APV plan). This type of savings can be done through a special account in one of the AFP, through special mutual funds offered by banks or other financial institutions and through life insurance-plus-savings contracts. By construction, this type of exemption mostly attracts voluntary savings from high income individuals, as these are subject to the highest marginal income tax rates. For most low and middle income workers, who are not even subject to income tax, regular tax exemptions provide no incentive to participate.

The reform makes two attempts to increase voluntary savings from dependent workers in general, but especially for those who do not benefit from regular tax exemptions. On the one hand, it creates the figure of Collective Voluntary Savings Plans (known is Spanish as APVC plans), a scheme that provides tax incentives for firms who provide matching-contributions plans for their workers. ${ }^{27}$ On the other hand, the reform provides two additional incentives for individual voluntary savings: i) workers can choose between tax exemptions when contributions are made or tax exemptions when they are withdrawn, and ii) workers can benefit from a State-financed $15 \%$ bonus on voluntary contributions (individual or collective) that are used to increase retirement benefits or apply for early retirement, with an annual maximum.

Following the experience of developed countries, there is enormous growth potential in the amount of old age wealth that can be accumulated through voluntary savings schemes. The creation of APVC plans is particularly interesting as a new form of non-pecuniary compensation that can be used by employers to attract and retain good workers, increasing the incentives for on-the-job training, while at the same time improving the amount of old age savings from middle income workers. It remains to be seen if tax incentives are enough to induce firms to create these plans and seize the opportunity to move towards this modern form of compensation.

\section{Subsidized social security contributions for young workers}

One particular aspect of defined contribution systems is that, due to the effect of compound interest over a long period, early contributions can have a great impact on final pensions. For this reason, and the interest to decrease youth unemployment, a special subsidy is created to pay for part of the social security bill of employers who hire workers between the ages of 18 and 35. More specifically, employers will be subsidized in an amount equivalent to $50 \%$ of the pension cost (contribution included commission) of a minimum wage worker, for the first 24 contributions of young workers earning less than 1.5 minimum wages.

\footnotetext{
27 APVC follow the same principle of $401 \mathrm{~K}$ plans in the United Status or other defined contribution occupational plans in other countries. Employers can establish savings contracts with any institution that provides APV individual plans (AFP, banks, mutual funds, and insurance companies), make matching contributions as a function of worker's contributions, and establish vesting periods. Conditions must be the same for all workers and, under no circumstances, can employers restrict benefits to certain groups.
} 
Additionally, a State-financed bonus equivalent to the hiring subsidy will be directly deposited in the worker's individual account, for the first 24 contributions between the ages of 18 and 35 that were made for a covered wage below 1.5 minimum wages.

\section{Additional tools for the supervision of contribution payment}

A key role for increasing contributory coverage is placed on the tools available to enforce employer's obligations to make contributions on behalf of their workers. Before the reform, when an employer stopped making contributions for a particular worker, it was difficult to verify whether the employment relationship had stopped or whether the employer was no complying with the law.

The Reform introduces a legal change under which circumstances where employers stop making contributions without formal reporting will be automatically considered as "declared but not paid". The AFPs will then be responsible for verify compliance and pursue all legal resources to make the employer pay for the absent contributions, if necessary.

Another recurrent source of verification problems is the use of paper declarations from the part of employers. These are often associated with collection mistakes and delays in accreditation of the contributions. It also makes difficult to prosecute faulty employers. The reform introduced an incentive to the use of more efficient filing mechanisms by allowing employers 3 additional days for fulfilling the legal requirement if they file contributions electronically. ${ }^{28}$

\section{III.2.1.2. Measures to improve gender equality in the pension system}

Special attention was given in the reform to introduce measures that could increase gender equality between men and women. In general, women tend to i) have long periods without contributions, usually associated with caring duties over children or other dependent relatives, ii) be hired in low remunerated occupations (relative to men with similar educational background), iii) retire earlier and iv) live longer. ${ }^{29}$ All these elements, combined in a pension system that provides no gender redistribution during the retirement phase, create significant differences in the benefit distributions of men and women.

On the other hand, retirement and disability benefits under the AFP scheme inherited many of the asymmetric design elements of previous regimes: women cannot provide survivorship benefits to their husbands (or the fathers of their children), unless they are disabled. This means that they are entitled to lower benefits from the workers' disability and survivorship insurance program while paying the same premium. At the

\footnotetext{
${ }^{28}$ Obligation will remain on the 10th of every month for contributions not filed electronically.

${ }^{29}$ Minimum retirement age is 60 for women and 65 for men. The report from the Presidential Committee for Pension Reform suggested increasing female retirement age to 65 but this recommendation was not included in the reform bill sent to Congress.
} 
same time, pension formulas do not have to reserve funds for husbands in case they outlive their wives, a regulation that increases women's benefits. In addition, mortality tables used to calculate benefits under a programmed withdrawal schedule are gender specific (which is consistent with this self-insured option) and insurance companies are allowed to make differentiated offers to men and women.

\section{Introduction of the New Solidarity Pillar}

To address these differences, the reform considers a number of measures. The main one is certainly the introduction of the New Solidarity Pillar, which, by design, will be more beneficial for women, as they are more likely to never have contributed or done so with less frequency than men. In addition, benefits are gender neutral, therefore benefiting women because their higher longevity.

\section{State financed Bonus to mothers for every child born or adopted}

The reform introduces a subsidized bonus to mothers, for every child born or adopted. The subsidy is equivalent to the contribution of a full time minimum wage worker for 18 months, and receives an annual rate of return (equivalent to the net average return of AFP's Fund C) from the day of birth until the mother reaches the age of 65 . This benefit is subject to the residency requirement but is not means tested.

Since Chile is among the countries with the longest maternity leave regulations in the region (18 weeks) and at the same time with one of the lowest female labor force participation rates, the introduction of this bonus is extremely important to achieve decent retirement income, particularly among low income workers. But beyond the financial benefit, the measure is extremely valued by the population, as a form of social recognition to the (non-remunerated) activity of giving birth and taking care of children during their first months of life.

\section{Economic compensation in case of divorce or annulment}

In addition, the reform introduces the legal concept of pension related economic compensation in case of divorce or annulment. Under this figure, a judge can instruct, if required, the transference of retirement funds between individual accounts, as a form of economic compensation to the part that presents a loss during the period they were married. This transference cannot exceed $50 \%$ of the resources accumulated in the account of the contributing part, during the period the two persons were married.

\section{Separation of disability and survivorship insurance contracts between men and women and transference of the difference in premia to the low-cost group individual accounts}

The premium that is charged to participants in the AFP system for the disability and survivorship insurance (SIS) was, before the reform, the same for men and women, despite the fact that these are less likely to become disabled and do not generate survivorship benefits to their spouses, unless they are disabled. To avoid this crosssubsidy, the reform requires AFPs to obtain separate insurance contracts for men and women, to charge affiliates for the higher of the new premia (most likely the men's contract) and deposit the difference for the other group in the savings account of the less risky group (most likely, women). As a result, women's final contribution to their pension funds will be slightly higher than the 10 percent prescribed in the law. This can 
be seen as a way to maintain a unique insurance cost for all participants, while increasing the amount of savings available to women at the time of retirement.

\section{Widower pensions}

As mentioned earlier, one of the main gender asymmetries prevailing in the pension system is the impossibility of generating survivorship pensions to widowers, unless they are disabled. As part of the reform, the requirement of reserving part of the accumulated funds at retirement for paying survivorship pensions and the coverage under the survivorship insurance are now applicable to both men and women. In the first case retirement calculation - the inclusion of widowers will actuarially decrease the pension of the retiring woman in exchange for the additional benefit. In the second case, the additional coverage will be financed by a unique insurance premium corresponding to all women in the system, therefore eliminating the current cross-subsidies from insured women to insured men.

The measures described in this subsection account for most of what can be done to improve pension equality between men and women through pension system design. ${ }^{30}$ Clearly, however, most of the pension inequality is associated with cultural factors governing the distribution of labor at the household level and the labor market distortions that occur through occupation or wage discrimination. These factors cannot be appropriately addressed through pension reforms.

\section{III.2.1.3. Measures to increase competition in the AFP industry ${ }^{31}$}

One of the main pillars of the reform introduced in 1980, was the introduction of competition between AFPs, as the central disciplining mechanism to ensure good performance, good quality of service, at a low cost. As participants could freely move between pension managers, expensive or underperforming AFPs would be punished by market forces. Reality has shown that competition in an industry where the service provided is compulsory and extremely complex for the average consumer and where benefits are only perceived in the long term, does not always take the form that was intended. In fact, during the 1990s, competition was strong, but based on an expensive system of sales personnel and presents for transferring from one AFP to another. This inefficient period of high cost marketing competition was replaced by a short period of mergers and acquisitions that resulted in the current state of affairs, characterized by a concentrated industry (6 firms manage funds equivalent to $60 \%$ of GDP), high returns on assets and no entry in the last 9 years. ${ }^{32}$

The interpretation of this phenomenon is both related to demand considerations (the low elasticity of demand caused by the characteristics of the product and the limited

\footnotetext{
${ }^{30}$ Some have argued that one further measure that could greatly improve women's pensions was not included in the reform: the equalization of retirement age at 65 . In a defined contribution context, however, it is not clear whether this is a significant improvement in women's welfare, as the increase in retirement income is directly compensated by the delayed retirement age, with no additional wealth being saved or transferred to women.

${ }^{31}$ For a comprehensive analysis of these measures, see Reyes (2008).

${ }^{32}$ See Valdes and Marinovic (2005) for a detailed accounting procedure of the return on assets exhibited by AFPs.
} 
product or price differentiation between providers) and supply considerations associated with a number of regulations that affect the industrial structure of the market. AFPs are required to provide a number of services: collection of contributions, record keeping, investment, customer service, as well as benefits calculation and payment. This creates in practice a multiple barrier to entry. This problem is exacerbated by regulations that limit the scope and benefits of outsourcing some of these activities: AFPs are not allowed to outsource record keeping or customer service and they are not allowed to provide services other than those stipulated by law. In addition, they do not collect value added tax (VAT) from the fees they charge to participants but they must pay VAT on the services contracted from outside providers, therefore generating a significant cost to outsourcing.

\section{Competitive bidding process for new members}

The reform addresses these issues affecting both the demand and supply side. ${ }^{33}$ On the demand side, elasticity is substantially increased by the introduction of competitive bidding process for new members. All new participants in the pension system will be automatically enrolled in the AFP that offered the lowest commission during the last bidding process. These affiliates will be required to stay in that AFP for a minimum period. $^{34}$ The winning AFP will therefore receive a constant inflow of participants for a period of two years, without having to incur in marketing or sales force costs. This measure creates an attractive starting point for potential new entrants, as incumbent firms cannot charge a different commission to different groups of participants (current affiliates or new workers).

\section{Fee structure}

Another explanation for the low sensitivity of demand, especially to the fees charged, is the complexity of comparison between firms that can charge multiple fees (some are constant in absolute terms and some are a fixed fraction of covered earnings). In an attempt to facilitate price comparison between AFPs, the commission structure was simplified by the reform to the point where AFPs can only charge a unique commission, expressed as a fixed proportion of covered earnings.

\section{Requiring or facilitating the outsourcing of certain functions of the AFP}

On the supply side, a number of measures tend to facilitate outsourcing of certain functions of the AFP. The range of services that can be outsourced is extensively broadened, and the AFPs receive a tax credit for the VAT paid to subcontractors.

One of these services, the disability and survivorship insurance (SIS) is now required to be contracted by the AFP system as a whole, instead of the previous situation under which each AFP had to take its own insurance and these contracts were designed in

\footnotetext{
${ }^{33}$ The reform bill sent to congress included a measure to allow local banks to enter the AFP industry by creating subsidiary firms. This measure was not approved by opposition parties, arguably to avoid the creation of a public AFP, as a subsidiary of the Banco del Estado de Chile.

${ }^{34}$ The affiliate can transfer to another manager if the winning AFP does not comply with the regulation or is consistently underperforming other administrators in a way that cannot be compensated by the difference in commissions.
} 
a way that most of the risk was born by the AFP itself. ${ }^{35}$ This created a strong incentive to compete in the ability to attract low risk individuals only, in detriment of good portfolio investment, cost reductions or quality of service. By requiring a system-wide insurance contract, the risk is effectively born by insurance companies and the incentive to out-select riskier individuals is eliminated. The design of the insurance bidding process will be subject to detailed regulation issued by the Superintendency of Pensions and the Superintendency of Insurance and Securities. By law, insurance coverage will have to be auctioned separately for men and women, and randomly assigned groups could be created and assigned to different firms to avoid excessive concentration of risks.

This measure implies an important change in the way the disability and survivorship insurance system is managed. While its mandatory separation will greatly reduce barriers to entry into the AFP industry, some have argued that it will greatly reduce their incentive to contain fraud, potentially causing an important increase in the insurance cost of the service. This is not a minor issue, considering that this component accounts for about $1 \%$ of covered earnings in the economy and careful consideration should be taken to maintain appropriate controls in the system.

\section{Permission for Insurance Companies to create AFP subsidiaries}

Looking to increase contestability in the AFP industry, insurance companies are now allowed to create subsidiaries as Pension Fund Administrators, subject to the regulation established in the Decree Law 3.500. These subsidiaries must strictly follow the sole purpose requirement for any AFP, i.e., it can only offer the services and products stipulated by law. Furthermore, the insurance company cannot its subordinate services or products to joining or staying in the AFP subsidiary or offer improved conditions for individuals in such circumstances.

\section{III.2.1.4. Flexibilization of the AFP investment regime}

To limit the absolute exposure of investment portfolios, the original regulation included a complex set of quantitative limits: limits by issuer, by emission, by asset class (including limits to variable income), by source of funds (domestic or foreign), etc. Most of these limits were written in the law that regulated the system, with little scope for interpretation or flexibility. The reform transferred most of these limits from the law into secondary regulations and a created a special investment council (the Investment Technical Council) whose function is to make recommendations regarding the investment policies and regulations of the Pension Funds. ${ }^{36}$

\footnotetext{
${ }^{35}$ Insurance contracts included ex-post adjustments that were equivalent to a risk transfer between the insurance company and the AFP, leaving insurance coverage only for extreme events.

${ }^{36}$ Only the main structural limits remained in the law, subject to a general upper bound, under which the Central Bank has the authority to set the actual limitation: A variable income limit for each type of fund; An overall foreign investment limit (which could reach up to $80 \%$ of the funds) which can substituted by specific limits for each type of fund; fund specific limitations to the amount of uncovered investment made in foreign currency; and finally, a limit to investment in financial instruments issued by institutions with less than 3 years of operation.
} 
Increased flexibility will be accompanied by increased transparency requirements in terms of explicit investment policies, as well as public policies to deal with conflicts of interests. The reformed law includes the possibility to establish limits based on portfolio risk measures instead of quantitative limits by assets classes.

\section{III.2.2. Expected impacts}

The reform described in this section is certainly one of the most comprehensive efforts undertaken in the region to both complement the contributive pillar with a strong poverty-prevention component and introduce a number of innovative solutions to improve, after 27 years, a second pillar based on individual capitalization accounts and market provision.

The introduction of the New Solidarity Pillar will greatly reduce income uncertainty in old age, by providing minimum coverage for everybody who does not have other means of financing. This will also reduce income inequality both among adults and in the population as a whole. In fact, it is not uncommon to see older individuals living in the same household with relatives. The new benefits will therefore improve the situation of the individuals, together with the families they live with.

The extension of coverage provided by the poverty-prevention pillar should be complemented by the increased contributions made by young and self-employed workers, as well as the additional voluntary savings that should be raised through collective voluntary savings arrangements. The experience in other countries, particularly developed ones, show the great potential that this type of firm related coverage can imply for a large segment of the population.

It is also expected that the measures taken to improve the industrial organization of the industry should reduce costs and facilitate entry of new competitors, by providing new firms access to a large critical mass of new workers without having to incur in marketing costs and by providing incentives for the external provision of certain activities. The separation of the disability and survivorship insurances will greatly reduce the uncertainty associated with having to provide this service for a firm that is just entering the market.

\section{III.2.3. Fiscal sustainability of the reform}

As the benefits from the New Solidarity Pillar were designed as entitlements to the population, the reform implies a significant commitment from the State to future generations of pensioners. While detailed information about the medium and long term impacts of the reform is limited, available data indicates that they might be relevant. The reform bill was accompanied by a financial statement, including estimations of fiscal costs from 2008 until 2025 (table III-2). This table presents the expected impacts of all provisions incorporated in the reform law, including some that might not be considered part of the pension reform in strict sense. In any case, the projections indicate that the fiscal cost of the reform should be below 0.5 percent of GDP in the first few years, to reach almost one percent of GDP by 2025. 
Table III-2 - Fiscal cost of the pension reform

(Million of Chilean pesos of 2007)

\begin{tabular}{|c|c|c|c|c|c|c|c|c|c|c|}
\hline & 2008 & 2009 & 2010 & 2011 & 2012 & 2013 & 2014 & 2015 & 2016 & 2017 \\
\hline 1.- Solidarity Pension System & 38898 & 177225 & 322283 & 432019 & 565631 & 656718 & 701641 & 751587 & 804330 & 86007 \\
\hline 2.- New Institutional framework & 6413 & 3914 & 2243 & 2467 & 2547 & 1048 & 1043 & 1034 & 863 & $\overline{85}$ \\
\hline 3.- Bonus to women for every child & 0 & 7049 & 14946 & 23537 & 33054 & 44596 & 49121 & 53181 & 57558 & $\overline{62311}$ \\
\hline 4.- Subsidy to young workers & 6657 & 27853 & 28979 & 44989 & 61835 & 63502 & 64977 & 66256 & 67158 & 6763 \\
\hline 5.- Family allowance for independent workers & 0 & 0 & 0 & 4937 & 10270 & 12815 & 15541 & 18455 & 21566 & 2488 \\
\hline 6.- Voluntary savings plans (individual and collective) & 6450 & 26243 & 27004 & 27734 & 28467 & 29195 & 29910 & 30604 & 31272 & 31 \\
\hline 7.- Fund for pension education & 689 & 1378 & 1432 & 1437 & 1469 & 1503 & 1539 & 1597 & 1615 & 165 \\
\hline 8.- Contribution for insurance of public servants & 0 & 21060 & 42660 & 42696 & 42732 & 42767 & 42803 & 42839 & 42875 & 4291 \\
\hline 9.- Worker’s compensation for self-employed workers & 381 & 392 & 403 & 413 & 424 & 434 & 444 & 453 & 462 & $\overline{47}$ \\
\hline 10.- Deduction of VAT on outsourced services by AFPs & 775 & 3133 & 3164 & 3196 & 3228 & 3260 & 3293 & 3326 & 3359 & 39 \\
\hline $\begin{array}{l}\text { TOTAL } \\
\quad \text { in \% of GDP (1) }\end{array}$ & $\begin{array}{r}60263 \\
0.07 \%\end{array}$ & $\begin{array}{r}268247 \\
0.30 \%\end{array}$ & $\begin{array}{r}443114 \\
0.47 \%\end{array}$ & $\begin{array}{r}583425 \\
0.60 \%\end{array}$ & $\begin{array}{r}749657 \\
0.73 \%\end{array}$ & $\begin{array}{r}855838 \\
0.80 \%\end{array}$ & $\begin{array}{r}910312 \\
0.81 \%\end{array}$ & $\begin{array}{r}969332 \\
0.83 \%\end{array}$ & $\begin{array}{r}1031058 \\
0.84 \%\end{array}$ & $\begin{array}{r}109610 \\
0.86 \%\end{array}$ \\
\hline
\end{tabular}

Note: (1) Percentages of GDP estimated considering Chile’s Central Bank estimation for 2007 and projections for 2008 and 2009, and 4.5\% medium term growth

Source: Dirección de Presupuestos, 2008. 
Financing of the reform was designed to maintain fiscal discipline and a rigorous application of fiscal policy based on structural surpluses. The main sources of financing are the following:

- The Pension Reserve Fund (created in 2006, and funded with fiscal surpluses),

- Reduction of fiscal liabilities originated in the transition from the PAYG to the fully funded system: reduction of the operational deficit of the National Pension Institute $^{37}$ and the interest accrued from recognition bonds issued by the State to workers from the previous system who switched to the new one,

- Resources originated in reallocations, expenditure efficiency and economic growth,

- During the first few years (the transition period), part of the interest earned on financial assets owned by the State.

\section{III.3. Pending challenges}

The most important aspect of the reform described in this section is that, rather than replacing the AFP system created in 1980, it improves it by integrating a Statefinanced poverty prevention pillar, extending the voluntary pillar to middle income workers and introducing a number of measures to increase coverage and competition in the AFP industry. It is the result of a two year long participatory process, preceded by extensive research and evaluation efforts.

A number of challenges remain to be addressed in the years to come, both regarding the implementation of this reform and longer term aspects. In the first group, the progressive implementation of the new solidarity pillar will probably face risks. On one hand, the actual number of potential beneficiaries is not clearly known, as it partially depends on future trends of wages, compliance, and pension fund returns. Also, organizing the new institutions, setting up the conditions to fully integrate the self employed workers into the system, and organizing the systems to identify beneficiaries of the new solidarity benefits and make the payments will demand a serious commitment by the government.

On longer term challenges, not necessarily addressed by recent reforms, the most important seems to be shared by most middle and high income countries in the planet: the uncertain increase in life expectancy and medical costs in old age. With the technological progress of the last decades came dramatic increases in life expectancy, based on ever more sophisticated medications and equipment. We currently have a reasonable idea of

\footnotetext{
${ }^{37}$ The INP is the institution in charge of administering the PAYG regimes that are still in place for workers who decided to stay in their previous schemes. With the reform, pension related activities of the INP are transferred to a new institution, the Instituto de Previsión Social, responsible for the administration of benefits under the New Solidarity Pillar.
} 
how long the current pensioners are going to live but little is known about life expectancy of the individuals who are just entering the labor market. It is quite possible that the current $10 \%$ contribution rate will be insufficient to fund adequate benefits for this increased life expectancy and it is not clear that generational differences will allow workers to remain on the labor market long enough to compensate. Most of the burden will be put in the ability of individuals to foresee these shortcomings and increase their voluntary savings but, if pension systems were created to avoid myopia, it is not obvious that this reaction will have the adequate timing and strength. More efforts must be put in place to improve predictions over this uncertain future and the necessary - often unpopular - measures must be taken to increase contribution rates or retirement age. 


\section{Institutions and policy making processes}

\section{IV.1. Motivations for focusing on the policymaking processes}

Up to this point this paper has described the design and performance of the pension system in Argentina and Chile, and it has examined with some detail the reforms recently adopted by both countries. This section will no longer concentrate on the specific content of these reforms, but rather it will introduce a discussion on the institutional and political patterns under which those policy changes have been accomplished. In this sense, this section focuses on the importance of policymaking processes and their influence on the features of policies and, more specifically, on pension policy.

Why is it relevant to discuss this in a paper regarding pension reform? To state it briefly, it is because the workings of the political institutions and the characteristics of policymaking processes play a role in pensions as they do in other areas of complex public policy. In general terms, looking at the characteristics of political processes gives recognition to the influence of those processes on public policies; in other words, public policies require policymaking capacity to be effective. More specifically, several significant features of public policies depend on the ability to strike and enforce intertemporal political and social agreements. The dissimilar capability of achieving these agreements will affect some critical attributes of policies, such as their stability, adaptability, sustained credibility, and coordination and coherence. In this manner, whether the workings of the policymaking process tend to facilitate or discourage cooperative outcomes in the political transactions game becomes a central question (Spiller, Stein and Tommasi 2003).

As will be discussed afterward, there are some particulars of pension policy which seem to aggravate the possible consequences stemming from the lack of adequate policymaking capacity and cooperative political environments. In the context of the market-oriented reforms in Latin America, the discussion concerning pension policy was frequently articulated around the "public vs. private" controversy, as if that choice on its own could solve all the complexity involved in this policy. Focusing on the institutional determinants behind pension policy highlights the potential influence of some permanent characteristics of the policymaking process that are beyond the "big title" of public system or private system ${ }^{38}$.

As stated previously, the different characteristics of the policymaking processes play a significant role in the performance of public policies. However, while measuring social outcomes from public policies is relatively simple, measuring institutional features

\footnotetext{
${ }^{38}$ In the context of the shift toward pension private administration that took place in Latin America during the '90s, it was frequently argued that "privatization" would eliminate political risk (defined as the risk of any type of wrong use of funds or inadequate interference in pension system by the government). However, with the reforms in place, it was quite evident that things were more complicated (see Kay 2003 for an analysis of Argentine case). As in other areas of policy reform, the weakness of oversimplified messages dealing with problems of high institutional and political complexity came out into the light; these problems inevitably require political cooperation on a regular basis. In other terms, it seems to be clear that it is not possible to get the government out of the pension system (Barr 2002).
} 
is much more difficult. More over, in the case of pension policy, even if these institutional indicators were readily available, showing a clear causal effect between them and the policy outcomes would still be very complex, partly because many of these outcomes can be fully observed over several decades after the adoption of policies, and partly because other primary determinants -such as a long term economic growth, labor market performance, or overall fiscal development- may have stronger short term impacts $^{39}$.

Section IV.2 advances with an exploratory approach, analyzing in what way political institutions and policymaking processes could matter for pension policy performance. After that, in section IV.3, some general attributes of the policies and the policymaking process of Argentina and Chile are explored; even if it is a very limited account, it will illustrate some key features of the institutional and political patterns in both countries. Section IV.4 presents some aspects of the recent pension policymaking processes in Argentina and Chile. But before moving on, we will briefly attempt to make two concepts more clear: intertemporal political cooperation and the characteristics of policymaking process.

Policies (at least complex policies, such as pensions) can be visualized as dynamic processes that involve multiple actors through their life cycle. This concept of policy (and consequently of policy reform) goes up against the more stereotypical oneshot policy implementation account, which implicitly assumes some kind of magical moment of special politics in order to produce effective policy results (Tommasi 2004). In a dynamic approach to the concept of policy, the recurring specific responses required from political, social, and economic agents have to be considered. Therefore one must contemplate the various forms of regular interaction required among them. Only if this interaction is supported by positive beliefs in the workings of the policymaking game as well as some attributes of the policy itself (such as its credibility and expected durability), can it become a "cooperative" interaction. At the same time, the policymaking game is conditioned by the workings of a set of political institutions (such as Congress, the party system, and the judiciary). These institutions, in turn, rely on some more basic institutional features of historical nature (Spiller and Tommasi 2003 broader develop this causality).

Concentrating on the characteristics of policymaking process leads to scrutinizing the connection between the kind of transactions that political actors are able to undertake and the possibilities provided by the institutional environment. The dynamic behavior of political actors (in accordance with the dynamic approach to policies that was emphasized before) will primarily depend on the actors' preferences. But, at the same time, their behavior will depend on their incentives, the constraints they face, and on the expectations they have regarding the actions of other players. Therefore, to delineate some characteristics of the different policymaking scenes, it is important to analyze who the key actors are that participate in the process, their powers, their preferences and incentives, their time horizons, the arenas in which they interact, and the nature of the transactions they undertake.

\footnotetext{
${ }^{39}$ For simplicity, since this is a paper concerning pensions and not political or institutional theory, we mention here the role of central economic concepts, such as growth and labor market performance, as if they were totally free from any institutional or political influence.
} 
In political environments that encourage intertemporal agreements, public policies will tend to be more consistent, less sensitive to political shocks, and more adaptable to changing economic and social conditions. In contrast, in settings that hinder cooperation, policies will be either too unstable (subject to political swings) or too inflexible (unable to adapt to socioeconomic shocks) and they will tend to be poorly coordinated (IDB 2006).

\section{IV.2. The specifics of pension policy and its political implications.}

Pension policy has some particular characteristics that make the process of designing and implementing it prone to trouble -and much more so in countries with limited institutional capacity for credible commitment.

Measured by the proportion of public expenditure it usually represents, pension policy is now the largest component of social policy in most developed economies. By the year 2000, pensions represented an average of 12.5\% of the EU members' GDP (Eurostat, 2002). That same year, the U.S. spending on pensions explained a third of the whole federal government expenditure (U.S. Census Bureau, 2004). Even if they do not reach the magnitude of the more developed world, pension expenditures in several Latin American countries are very substantial as well, and they have shown persistent growth during the last few decades. As it is well-known, there is a demographic determinant behind these expenditure patterns. As populations age, the elderly represent a growing proportion of the population, creating heavier demands on the working-age population, and so, pension policy becomes a more complex subject to deal with.

Secondly, pension policy has been characterized by a multiplicity of goals, which exhibit some inherent degree of trade-off. Policymakers who design pension systems have to simultaneously provide the best possible benefits to the largest possible number of beneficiaries at the lowest possible cost (Rofman 2003). In more theoretical terms, even the proper definition of pension policy seems to be a frequent subject of disagreement. Nobody denies that it is in itself an explicit distributive policy; however, there is no such consensus concerning what constitutes the main matter of redistribution, in which way this redistribution has to be accomplished, and among whom the policy is supposed to redistribute. In practice, the distributive function that most pension schemes usually perform is multifaceted, meaning it operates simultaneously on different levels. Probably, the most recognized of these levels is the redistribution of monetary income, which in turn works through multiple stages: intertemporally from an individual point of view, between generations and, most often, intra-generationally. But the design of the pension system also determines the distribution of rights (access to the system) and a set of risks (demographic, economic, financial, labor market). It has been suggested that pension systems also play a key role in the redistribution of jobs; in an overview of some empirical facts released by 89 pension systems in the mid '90s, Mulligan and Sala-iMartin (1999) found that three-fourths of them explicitly encouraged retirement in order to be eligible for a pension benefit (including compulsory clauses in half of the cases).

Finally, there is an aspect of pension policy that is unique. It should be taken into account that any pension system, in being a mechanism for distributing rights over the future social output, is inevitably based on some kind of promise (Barr 2002). The 
temporal compromise that underlies this promise is absolutely exceptional. From an individual perspective, we are facing the longest time-cycle a single public policy can possibly run. Novice formal workers in their twenties are having money taken from them, in exchange for the promise that the money will be returned in around 40 years. As it is easy to visualize, this cycle fits perfectly with our previous reference to the set of risks pension policy has to manage; there are so many things that could go wrong along those 40 years, that it is no wonder that pension systems are such hot political problems in almost any country.

In short, we are dealing with a policy that i) handles huge relative amounts of money, wherein ii) implicitly resides a sort of "agreement” of outstanding durability, and that iii) must arbitrate several distributive dilemmas of an atypical degree of complexity. In this sense, pension policy (much more than any spot-transactional policy) seems to be particularly suitable in reflecting the significance of having good capacity to perform intertemporal agreements.

But it should be highlighted that the political challenge behind pension policy goes beyond the fulfillment of some specific and well-defined long-term promise. In being such a complex distributional issue, the concrete form adopted by the pension arrangement needs to be politically and socially reshaped over time. Thus, the real challenges reside in having appropriate political configurations to articulate, channel, and control that dynamic process. These political configurations can exhibit a broader or more restricted "institutional density": they can display a different degree of inclusion of relevant actors; they can offer dissimilar time-horizons for these actors (longer time horizons make it easier to enter into the intertemporal agreements necessary to sustain effective policies); they can exhibit either more adequate or more deficient political arenas for interaction; they can assume or exclude more representative and democratic mechanisms of articulating interests; and they can contemplate more or less credible enforcement technologies (such as an independent judiciary, or a strong bureaucracy to which certain public policies can be delegated).

\section{IV.3. A general picture of the main political characteristics in Argentina and Chile}

This sub-section introduces some generic characteristics of policies in Argentina and Chile and presents some aspects of their policymaking processes that are significant to pension policy. The purpose here is not to demonstrate but simply to illustrate a fact widely accepted in literature -that both countries show different characteristics in their policymaking processes as well as dissimilar abilities to generate and sustain cooperative political games.

What probably constitutes the most notable aspect in differentiating public policy in Argentina and Chile is its degree of stability, reflected both in particular policy areas as well as in the core of their economic strategies. Both from international data sets and from comparative studies, it is quite visible that in the last decades their economic models have exhibited a different degree of constancy. After a comparable pro-market turn realized in the mid '70s, Chile continued to follow that path while Argentina appeared much more volatile in its central economic decisions. The unpredictability of economic policy in Argentina has been found to produce high uncertainty costs from economic 
agents. The greater the volatility of the most important variables, the greater the propensity of the economy to create systematic disequilibria. An economy with such characteristics induces some microeconomic behaviors that would otherwise be absent and, as a result, the harmful influence of macro determinants on micro-structure will be much more permanent and visible (Fanelli and Frenkel 1994).

At times, volatility in Argentina has impeded the enforcement of policies the country had enacted and has led to self-imposed rigid routines as a means to achieve a little political credibility. An example of this mechanism is the management of inflation. By the late ' 80 s, this problem spun out of control driving the economy toward hyperinflation episodes -episodes with huge social and political consequences. The new administration, after a couple of failed attempts to control inflation, established the socalled Convertibility regime. The Convertibility was an extremely strict monetary rule that kept the domestic currency tied to the dollar, taking money supply totally out of the policymaker control (with the obvious purpose of positively influencing people's expectations about monetary policy). After some years of apparent success, the rigidity and limitations of this regime became evident and the Convertibility plan blew up in late 2001 in the middle of another huge crisis, with another government leaving office prematurely. In this way, extreme rigidity ended up being a (very high) price to pay for extreme volatility ${ }^{40}$.

Stability is not the only aspect that differentiates policies in both countries. For instance, Stein and Tommasi (2005) have categorized eighteen Latin American countries in accordance to several other features of public policies such as their adaptability, quality of implementation, coordination, public-regardness and efficiency. In that research, as well as in several studies dealing with the measurement of the characteristics of policies in Latin America, Chile consistently ranks at the top of the scale, while Argentina is at the lowest third of the ranking.

Even if it is not possible to achieve a full understanding of any country's political process choosing single "pieces" from its institutional map, we will briefly comment on certain aspects of the policymaking in Argentina and Chile.

The anatomy of political parties, the role of Congress, and the actual influence of governors compose an intricate triangle, which differs profoundly in both countries. Chile has two well-defined major coalitions, the Concertación (in office since 1990) and the Alianza. The electoral rules highly enforce intra-coalition discipline by reducing the incentive of single parties to leave them, which in turn reduces the number of relevant political actors. In a recent study on the policymaking in Chile, its political party system (and its links with the rest of the political game) was identified as the essential foundation for political cooperation (Aninat et al. 2006) ${ }^{41}$. On the other hand, Argentina has also

\footnotetext{
${ }^{40}$ As stated, inflation is a recurring source of trouble in Argentina. In 2007, in the context of rising prices, the government carried out a controversial "intervention" in the National Bureau of Statistics (INDEC) with the aim of changing the way inflation was being measured. Every top and middle official in charge of the price indexes and other related surveys was replaced and the methodological changes have not been clarified to this day by the government. This episode suffered high repercussions in the media and the credibility of INDEC data notably decreased.

${ }^{41}$ The authors sustain: "Repeated interaction between the parties not only makes it possible for them to make (and keep) policy deals, but it more importantly creates an incentive for the parties to maintain their
} 
presented two major parties in recent decades. However, the real workings of its political party scene are much more intricate. This is related to the fact that Argentina (unlike Chile) is a federal country made up of 24 provinces with substantial constitutional powers. This difference is far from representing just a formality since the workings of Argentine federalism are extremely complex and constitute a central part of its political scenario. Provincial governors have proved to be key political actors, not just in their local territories but in the national political game.

The political weight of Congress is also unequal in both countries. Argentine legislators face high rotation, resulting in a lower level of experience and specialization, and little incentives to become more professional (Jones et al. 2002, Jones et al 2003). In consequence, Congress in Argentina has not worked as a crucial arena in policymaking process. The Chilean Congress, in contrast, has been described as unusually professional and competent by Latin American standards, becoming a place in which the relatively prolonged trajectory and expertise of legislators turn into institutional competence (Montecinos 2003; Santiso 2006; Aninat et al. 2006). A strong Congress, besides being a reservoir of technical skills, clearly becomes a privileged arena where intertemporal cooperative practices can be developed to make public policies more effective and reliable.

The workings of civil service and the judiciary could be seen as another two major institutional nodes in which both countries have shown disparities. A qualified bureaucracy can be important both in its role of implementing public policies and as an additional channel for the intertemporal enforcement of political agreements. Argentina, however, in part due to past political instability, but also to the current incentives of key political players, has not achieved such a professional bureaucracy. Civil service policies in Argentina during the last few decades have been considered erratic; the political views regarding the employment regulation regime have largely fluctuated. In contrast, since the turn to democracy, Chile has carried out civil service reforms through a more gradual and "additive" criterion, in which the different initiatives have strived to combine with their previous accomplishments -causing fewer policy swings compared to other countries experiences (Iacoviello and Zuvanic, 2005).

The judiciary, habitually recognized as a major enforcement technology overseeing a country's political system, seems to also have presented different characteristics in both countries. Iaryczower et al. (2002) analyze the decision-making patterns of the Argentine Supreme Court over decades and conclude that it tended to be too aligned with the executive branch, generating a loss of credibility. In a comparative study using Latinobarometer data from 1997, Malone (2003) found that Chileans generally regard their judiciary as more accessible than Argentineans, and that differences about perceptions of efficiency were minor.

Going back to the more conceptual approach used at the beginning of this section, what have been briefly described here are parts of two dissimilar institutional and

ideological "brand names" with the voters -thus constraining the sort of policy changes they align themselves with". (Ibíd, p.40). In Argentina, in contrast, ideological brand names of parties have been much more confusing and ambiguous. Perhaps, the most notable image of this was the "switch" performed by President Menem (who belonged to the Peronista Party) in the early '90s when, once in office, surprised everybody -particularly his voters- with a widespread pro-market reform. 
political configurations that seem to foster cooperative behaviors to a very different degree. Key actors in Argentina seem to have had shorter horizons and worse incentives. Political agreements are weaker, which results in weakened incentives to work towards those agreements in the first place. In addition, the political weakness of Congress has frequently moved the center of the political scene away from the national legislature and toward other informal arenas -ones that have not been structured for the institutional enforcement of bargains (Spiller, Stein and Tommasi 2003). On the other hand, since the return of democracy, Chile has exhibited stronger mechanisms in its policymaking process. Policy changes have been incremental and, in general, they have resulted as the outcome of a relatively intense and institutionalized political process. In sum, Chile seems to have a policymaking process that tends to facilitate cooperative outcomes in the political transactions game, a dynamic that Argentina has found more difficult to build.

\section{IV.4. Some concluding remarks}

This section concludes looking at some highlights of the recent pension policymaking in Argentina and Chile. The latest reforms were adopted under quite different mechanisms in both countries. Those different mechanisms seem to match closely with the divergent characteristics of political processes that have been considered. For that reason, some previous aspects of pension policy in both countries (and the "atmosphere" surrounding pension debate) will be briefly alluded to.

Both Chile's (1980) and Argentina's (1993) original pension reforms were presented as "icons" of broader policy reform processes at their time. Chile's reform was probably the best known of the so-called "modernizations" performed by the military regime. Argentine reform was a significant piece of President Menem's wide pro-market economic policy in the '90s. In being such "icons", the reforms were surrounded by a notable communication battle between promoters and opponents, which ended up being called the "privatization" of pensions. Borzutzky (2002) argued that the pension reform publicity campaign, the most expensive in Chile's history according to the author, "stressed the issues of modernity and self-reliance involved in the new system, as opposed to the politicization, chaos, and crisis involved in the old one" (Ibíd p. 217). Also in Argentina the reform was politically introduced as something "up-and-coming" in contrast to the notorious, deficient, and broken old pension system.

But the Argentine reform of 1993 did not completely eliminate the old system; the law that was finally approved, unlike the Chilean system and the President's original proposal, did not close the pay-as-you-go scheme and created a true multipilar model. This phenomenon has not been trivial in the "public" vs. "private" controversy previously mentioned. Despite the fact of its legitimate importance, this singular controversy seems to have dominated all public debates regarding pensions in Argentina. At the time the reform was introduced, authorities explicitly promoted the advantages of the newly created private system of individual accounts and encouraged people to join in, but there was no objective and well-organized informative strategy to educate workers about their choices. (Isuani et al. 1995).

As in other policy fields, the Concertación governments in Chile have opted for continuity over radical change, and they have consistently supported the new pension system. Since 1990, reforms to the pension system had been minor, mostly affecting the 
investment regulations. Only in recent years the question of coverage emerged as a critical problem and became the center of policy debates.

On the other hand, in Argentina the terms of the discussion concerning pension system have persistently survived and "privatization" has continued to be the axis where the political and public debates have frequently rotated. In fact, the main message transmitted by authorities with regards to the recent reforms has been that workers would "recover" the possibility to switch from the "private" to the "public" system (which before was not an alternative).

In conclusion, the processes underlying the recently passed reforms in both countries are clearly different and resulted in different systems. Pension reform has been recognized as a process that requires careful and thorough technical analysis, as well as communication strategies in order to build support and consensus (IDB 2007). In that sense, in March 2006, Chile's President created a Presidential Advisory Council on Pension Reform to review the system performance, study its most important deficits, and carry out a extensive process of public hearings which lasted 90 days. The Council which was made up of respected specialists in the field- produced a full diagnostic assessment and proposed several reforms. Subsequently, the government established a Committee of Ministers to assess the Council's recommendations, the outcome of which was a comprehensive proposal for pension reform that was submitted to Congress and approved in January 2008. On the other hand, most of the recent reforms in Argentina have had limited analysis, and were approved either by decree or by laws that Congress approved with no inputs from experts, civil society or representatives of interest groups, and with little debates among legislators. 


\section{Conclusions}

Argentina and Chile are among a few countries in the region that have traditionally pioneered the implementation of reforms in social policies. The two countries are among a small group that introduced pension systems in their legislation in the early 1900s, and then advanced through different stages including more workers. In 1980, Chile pioneered again by introducing a structural reform that, among other important changes, created a privately run system of pension funds. Argentina, with some differences, followed Chile's model a decade later, when the traditional PAYG scheme was converted into a multipilar system.

The pioneering tradition continues at the end of the first decade of this Century, as both countries introduced important reforms to their pension system once more. This time, the reforms clearly shared some objectives, such as the expansion of old-age coverage and a redefinition of the role of the State in ensuring ample access to benefits. However, there were important divergences in other aspects, partially due to differences in views and policy making processes.

The reforms in Argentina resulted in an immediate and dramatic increase in coverage, as the number of pensions grew by 50 percent within one year. Also, the reforms resulted in a much larger role to the public PAYG scheme, as many workers were transferred, through choice or compulsory, from the funded scheme to the public system. Moreover, it was defined that, by default, new workers will also join this scheme, unless they explicitly indicate their preference to enroll in a pension fund. Other changes have affected benefit values for current and future beneficiaries, and some specific aspects of the funded scheme. So far, there have been no official estimates of the fiscal impact of the reforms, either in the short or medium term.

In Chile, instead, most reforms will have a gradual effect over time. The number of beneficiaries of the new "Solidarity Pillar" will be limited, but it will increase as the system is fully implemented. This is clearly the most important component of the new law, which should result in a nearly universal coverage of the pension system in the near future. Other reforms affect the operational aspects of the existing system, and the institutional structure of the supervisory and implementing governmental agencies. Also, a number of changes aimed at eliminating some inequities in the system, especially with regards to gender differences where introduced in the system.

The design and approval of these reforms followed a very different process in each country, as a consequence of the prevalent political and institutional context. The Chilean reform started when President Bachelet announced her interest, and set up a Council of experts. Two years later, after many debates, publications and analyses, the law was approved. In Argentina, most decisions were taken rather quickly at the highest level of the Government, and debates were limited and very short. These differences are probably a contributing cause for the different results and, as such, are worth of further study and analyses.

The slower and stepwise approach taken by Chile's authorities will probably ensure more sustainable and better calibrated results for their reforms than in Argentina. On the other hand, the bolder, faster reforms of Argentina resulted in an immediate 
response to a current problem. Most elderly excluded from the system received a pension benefit within a year, improving their welfare immediately, while in Chile the process to reach all beneficiaries will be more gradual.

Clearly, neither system has reached a "final" design, as there are remaining policy challenges that authorities will need to consider in the near future, and new problems or issues will probably emerge in the future. The ability of future governments to respond adequately to these challenges will certainly define the well being of future generations of Chileans and Argentines. 


\section{References}

- ANSES, 2007, “Informe de la Seguridad Social, Segundo Trimestre 2007”. Buenos Aires

- Arenas de Mesa, Alberto (2000) "Cobertura Previsional en Chile: Lecciones y desafíos del sistema de pensiones administrado por el sector privado”. Serie Financiamiento del Desarrollo, No. 105. ECLAC, Santiago.

- Arenas de Mesa, Alberto and Bertranou, Fabio (1996) "Learning from Social Security Reforms: Two Different Cases, Chile and Argentina”. World Development, Vol 25 No. 3

- Arenas de Mesa, Alberto, Bravo, David, Behrman, Jere R., Mitchell, Olivia S. and Todd, Petra, (2006), "The Chilean Pension Reform Turns 25: Lessons from the Social Protection Survey". NBER Working Paper No. W12401

- Barr Nicholas (2002): The Pension Puzzle: Prerequisites and Policy Choices in Pension Design. IMF. Economic Issues Series N.29, Washington, DC

- Berstein, Solange (2007), "El Sistema Chileno de Pensiones", Chilean Superintendence of Pension Fund Administrators

- Berstein, Solange; Larrain, Guillermo and Pino, Ariel (2006), "Chilean Pension Reform: Coverage Facts and Policy Alternatives", Economia 6(2), 227-279.

- Bodou, Amado; D’Elia, Vanesa and Lo Valvo, Ezequiel (2007) “El Plan de Inclusion Previsional. Resultados Preliminares”. Estudios Especiales de la Seguridad Social, ANSES, Buenos Aires

- Budget Office, Financial Report Reg 05SS, January 1, 2008

- Corbo, Vitorio and Schmidt-Hebbel, Klaus (2003), "Efectos Macroeconómicos de la Reforma de Pensiones en Chile. Resultados y Desafíos de las Reformas a las Pensiones," Federación Internacional de Administradoras de Fondos de Pensiones. Edited by CIEDESS

- Dirección de Presupuestos (2008) Informe Financiero Sustitutivo. Informe Financiero 01/2008. Ministerio de Hacienda, Santiago.

- Economic Commission for Latin America and the Caribbean, ECLAC (2006), "Shaping the Future of Social Protection: Access, Financing and Solidarity", Thirty first session of ECLAC, Montevideo, Uruguay

- Eurostat (2002): Social protection: expenditure on pensions. Statistics in focus Population and Living Conditions. Theme 3 - 6/2002 European Communities.

- Fajnzylber, Eduardo (2006), “Pensiones para Todos”, documento En Foco 65, Expansiva, www.expansiva.cl

- Fanelli José and Frenkel, Roberto (1994): Estabilidad y Estructura: interacciones en el crecimiento económico. CEPAL-CIID "Reestructuración productiva, Organización industrial y competitividad internacional para América Latina”. Santiago de Chile. 
- Farrall, Andres; Pena, Hernan, and others (2003) "Estudio sobre la frecuencia de los aportes en el SIJP Una primera aproximación hacia las historias laborales” in Historias Laborales en la Seguridad Social. MTESS and ILO, Buenos Aires

- Goldschmit, 2008 “Income Support in Argentina. Provincial Policies”. Mimeo, Buenos Aires

- Holzmann, Robert and Hinz, Richard (2005), "Old-age Income Support in the 21st Century", World Bank: Washington, D.C., pp. 73-140

- Iaryczower, Matías; Spiller, Pablo and Tommasi, Mariano (2002): Judicial DecisionMaking in Unstable Environments: The Argentine Supreme Court, 1936-1998. American Journal of Political Science, 46, Oct., (4): 699-716.

- Inter-American Development Bank - IDB (2006): "The politics of policies. Economic and Social Progress in Latin America - 2006 Report" IADB - David Rockefeller Center for Latin American Studies - Harvard University. Washington, DC.

- Inter-American Development Bank - IDB (2007): Chile: Strengthening of Pension System Management and Information. Report of the Institutional Capacity Assessment System (ICAS).

- Isuani, Aldo and San Martino, Jorge (1995): El nuevo sistema previsional argentino. ¿Punto final a una larga crisis? Boletín Informativo Techint $\mathrm{N}^{\circ} 281-282$. Buenos Aires.

- Jones, Mark; Saiegh, Sebastian; Spiller, Pablo and Tommasi, Mariano. (2003): Keeping a Seat in Congress: Provincial Party Bosses and the Survival of Argentine Legislators. UdeSA, Mimeo. Buenos Aires.

- Jones, Mark; Saiegh Sebastian and Tommasi, Mariano (2002): Amateur Legislators, Professional Politicians: The Consequences of Party-Centered Electoral Rules in Federal Systems. American Journal of Political Science. July, 656-669.

- Malone, Mary Fran (2003): An Uneasy Partnership? Democratization and the Rule of Law in Latin America. Paper presented at the annual meeting of the American Political Science Association. Philadelphia, Aug 27, 2003.

- Ministry of Economy - MECON (2007) “Series de Gasto Publico Consolidado". MECON, Buenos Aires.

- Montecinos, Verónica (2003) Economic Policy Making and Parliamentary Accountability in Chile. Democracy, Governance and Human Rights Programme, Paper $N^{\circ}$ 11. United Nations Research Institute for Social Development. Geneva.

- Moreno, Juan Martin (2007) "Se Acuerda, Abuelo, cuando las jubilaciones en Argentina eran Bismarckianas?” Paper presented at the XI Population Argentine Conference. AEPA.

- Mulligan, Casey and Sala-i-Martin, Xavier (1999): Gerontocracy, Retirement, and Social Security. National Bureau of Economic Research. Working Paper Series (WP No 7117). Cambridge, MA.

- Reyes, G. (2008): “Medidas Pro-Competencia de la Reforma Previsional,” Mimeo. Documentos de Trabajo (forthcoming). Superintendencia de AFP, Santiago 
- Rofman, Rafael and Lucchetti, Leonardo (2006) "Pension Systems in Latin America. Concepts and Measurements of Coverage” SP Discussion Papers 0616. Washington, DC

- Rofman, Rafael (2003): The Pension System and the Crisis in Argentina: Learning the Lessons. World Bank. Background Paper for Regional Study on Social Security Reform, Office of the Chief Economist, Latin America and Caribbean Region. Washington, DC.

- Santiso, Carlos (2006): El día que me quieras: parlamentos y presupuestos en América Latina. In "Cada cual ¿atiende su juego? El rol del Congreso en el presupuesto nacional de la Argentina" Fundación CIPPEC. Buenos Aires.

- Secretaria de la Tercera Edad, MDS (2000) Informe sobre la Tercera Edad. Buenos Aires, Ministerio de Desarrollo Social

- Spiller Pablo; Stein, Ernesto and Tommasi, Mariano (2003): Political Institutions, Policymaking Processes, and Policy Outcomes. An Intertemporal Transactions Framework. IADB. Washington, DC.

- Spiller, Pablo and Tommasi, Mariano (2003): The institutional foundations of public policy: a transactional approach with application to Argentina. Journal of Law, Economics, and Organization. 19, (2): 281-306.

- SAFJP (2007) "El régimen de capitalización y el sistema previsional, 1994-2007”. Buenos Aires

- Social Security Secretary - SSS (2002) “Libro Blanco de la Seguridad Social”. MTESS, Buenos Aires

- Stein, Ernesto and Tommasi, Mariano (2005): Democratic Institutions, Policymaking Processes, and the Quality of Policies in Latin America. IADB. Washington, DC.

- Tommasi, Mariano (2004): Crisis, Political Institutions, and Policy Reform. The Good, the Bad and the Ugly. In Tungodden, Bertil, Nicholas Stern and Ivar Kolstad, (eds.) "Toward Pro-Poor Policies. Aid, Institutions and Globalization". World Bank and Oxford University Press.

- U.S. Census Bureau (2004): Consolidated Federal Funds Report for Fiscal Year 2004. U.S. Government Printing Office, Washington, DC.

- World Bank (1994), "Averting the Old Age Crisis: Policies to Protect the Old and Promote Growth", Oxford University Press/ World Bank. New York 


\section{Social Protection Discussion Paper Series Titles}

No. $\quad \underline{\text { Title }}$

0831 Reforming the Pension Reforms: The Recent Initiatives and Actions on Pensions in Argentina and Chile by Rafael Rofman, Eduardo Fajnzylber and German Herrera, May 2008 (online only)

0830 Community-based Risk Management Arrangements: An Overview and Implications for Social Fund Programs

by Ruchira Bhattamishra and Christopher B. Barrett, October 2008

0829 Work History and the Access to Contributory Pensions in Uruguay: Some Facts and Policy Options

by Marisa Bucheli, Alvaro Forteza and Ianina Rossi, May 2008 (online only)

0828 A Theory of Contribution Density and Implications for Pension Design by Salvador Valdés-Prieto, July 2008 (online only)

0827 On the Financial Sustainability of Earnings-Related Pension Schemes with "Pay-As-You-Go" Financing

by David A. Robalino and András Bodor, July 2008 (online only)

0826 An Ex-Ante Evaluation of the Impact of Social Insurance Policies on Labor Supply in Brazil: The Case for Explicit Over Implicit Redistribution by David A. Robalino, Eduardo Zylberstajn, Helio Zylberstajn and Luis Eduardo Afonso, July 2008 (online only)

0825 The Portability of Pension Rights: General Principals and the Caribbean Case by Alvaro Forteza, May 2008 (online only)

0824 Pension Systems and Reform Conceptual Framework by Robert Holzmann, Richard Paul Hinz and Mark Dorfman, September 2008 (online only)

0823 Mandated Benefits, Employment, and Inequality in a Dual Economy by Rita Almeida and Pedro Carneiro, August 2008 (online only)

0822 The Return to Firm Investments in Human Capital by Rita Almeida and Pedro Carneiro, June 2008 (online only)

0821 Population Aging and the Labor Market: The Case of Sri Lanka by Milan Vodopivec and Nisha Arunatilake, August 2008 (online only) 
0820 China: Improving Unemployment Insurance

by Milan Vodopivec and Minna Hahn Tong, July 2008 (online only)

0819 Management Information Systems in Social Safety Net Programs: A Look at Accountability and Control Mechanisms by Cesar Baldeon and Maria D. Arribas-Baños, August 2008 (online only)

0818 Guidance for Responses from the Human Development Sectors to Rising Food Prices by Margaret Grosh, Carlo del Ninno and Emil Daniel Tesliuc, June 2008 (Revised as stand-alone publication)

0817 Levels and Patterns of Safety Net Spending in Developing and Transition Countries by Christine Weigand and Margaret Grosh, June 2008 (online only)

0816 Labor Regulation and Employment in India’s Retail Stores by Mohammad Amin, June 2008 (online only)

0815 Beyond DALYs: Developing Indicators to Assess the Impact of Public Health Interventions on the Lives of People with Disabilities by Daniel Mont and Mitchell Loeb, May 2008

0814 Enforcement of Labor Regulation and Firm Size by Rita Almeida and Pedro Carneiro, May 2008 (online only)

0813 Labor Markets Lending and Analytical Work at the World Bank: FY20022007

by Milan Vodopivec, Jean Fares and Michael Justesen, May 2008

0812 Risk and Vulnerability Analysis in the World Bank Analytic Work: FY20002007

by Valerie Kozel, Pierre Fallavier and Reena Badiani, May 2008

0811 Pension Lending and Analytical Work at the World Bank: FY2002-2007 by Richard Hinz, Melike Egelmelzer and Sergei Biletsky, May 2008 (online only)

0810 Social Safety Nets Lending and Analytical Work at the World Bank: FY2002-2007 by Margaret Grosh and Annamaria Milazzo, May 2008

0809 Social Funds as an Instrument of Social Protection: An Analysis of Lending Trends - FY2000-2007 by Samantha De Silva and June Wei Sum, July 2008 
0808 Disability \& Development in the World Bank: FY2000-2007

by Jeanine Braithwaite, Richard Carroll, and Karen Peffley, May 2008

0807 Migration, Labor Markets, and Integration of Migrants: An Overview for Europe

by Rainer Münz, April 2008 (online only)

0806 Is the Window of Opportunity Closing for Brazilian Youth? Labor Market

Trends and Business Cycle Effects

by Michael Justesen, April 2008

0805 Disability and Poverty: A Survey of World Bank Poverty Assessments and Implications

by Jeanine Braithwaite and Daniel Mont, February 2008

$0804 \quad$ Poverty Traps and Social Protection

by Christopher B. Barrett, Michael R. Carter and Munenobu Ikegami,

February 2008

0803 Live Longer, Work Longer: Making It Happen in the Labor Market by Milan Vodopivec and Primoz Dolenc, February 2008 (online only)

0802 Disability in Kazakhstan: An Evaluation of Official Data

by Ai-Gul S. Seitenova and Charles M. Becker, February 2008 (online only)

0801 Disability Insurance with Pre-funding and Private Participation: The Chilean Model

by Estelle James, Augusto Iglesias and Alejandra Cox Edwards, January 2008

0719 The Life-Course Perspective and Social Policies: An Issues Note by A.L. Bovenberg, November 2007

0718 Social Safety Nets and Targeted Social Assistance: Lessons from the European Experience

by Chris de Neubourg, Julie Castonguay and Keetie Roelen, November 2007 (online only)

0717 Informality and Social Protection: Preliminary Results from Pilot Surveys in Bulgaria and Colombia

by Franco Peracchi, Valeria Perotti and Stefano Scarpetta, October 2007

(online only)

0716 How Labor Market Policies can Combine Workers’ Protection with Job Creation: A Partial Review of Some Key Issues and Policy Options by Gaëlle Pierre and Stefano Scarpetta, October 2007 (online only) 
0715 A Review of Interventions to Support Young Workers: Findings of the Youth Employment Inventory by Gordon Betcherman, Martin Godfrey, Susana Puerto, Friederike Rother, and Antoneta Stavreska, October 2007

0714 Performance of Social Safety Net Programs in Uttar Pradesh by Mohamed Ihsan Ajwad, October 2007

0713 Are All Labor Regulations Equal? Assessing the Effects of Job Security, Labor Dispute and Contract Labor Laws in India

by Ahmad Ahsan and Carmen Pagés, June 2007

0712 Convention on the Rights of Persons with Disabilities: Its Implementation and Relevance for the World Bank by Katherine Guernsey, Marco Nicoli and Alberto Ninio, June 2007

0711 Reaching the Poor and Vulnerable: Targeting Strategies for Social Funds and other Community-Driven Programs

by Julie Van Domelen, May 2007

0710 The Macedonia Community Development Project: Empowerment through Targeting and Institution Building by Caroline Mascarell, May 2007

0709 The Nuts and Bolts of Brazil’s Bolsa Família Program: Implementing Conditional Cash Transfers in a Decentralized Context by Kathy Lindert, Anja Linder, Jason Hobbs and Bénédicte de la Brière, May 2007 (online only)

$0708 \quad$ Globalization and Employment Conditions Study by Drusilla K. Brown, April 2007

0707 The Kosovo Pension Reform: Achievements and Lessons by John Gubbels, David Snelbecker and Lena Zezulin, April 2007 (online only)

$0706 \quad$ Measuring Disability Prevalence by Daniel Mont, March 2007

0705 Social Safety Nets in World Bank Lending and Analytic Work: FY20022006 by Annamaria Milazzo and Margaret Grosh, March 2007 (online only)

$0704 \quad$ Child Labor and Youth Employment: Ethiopia Country Study by Lorenzo Guarcello and Furio Rosati, March 2007 
0703 Aging and Demographic Change in European Societies: Main Trends and Alternative Policy Options

by Rainer Muenz, March 2007 (online only)

0702 Seasonal Migration and Early Childhood Development by Karen Macours and Renos Vakis, March 2007

0701 The Social Assimilation of Immigrants by Domenico de Palo, Riccardo Faini and Alessandra Venturini, February 2007 (online only)

0616 Pension Systems in Latin America: Concepts and Measurements of Coverage by Rafael Rofman and Leonardo Lucchetti, September 2008 (online only). Also available in Spanish.

0615 Labor Market Outcomes of Natives and Immigrants: Evidence from the ECHP

by Franco Peracchi and Domenico Depalo, November 2006 (online only)

0614 The Relative Merits of Skilled and Unskilled Migration, Temporary and Permanent Labor Migration, and Portability of Social Security Benefits by Johannes Koettl under guidance of and with input from Robert Holzmann and Stefano Scarpetta, November 2006 (online only)

0613 The Limited Job Prospects of Displaced Workers: Evidence from Two Cities in China by Gordon Betcherman and Niels-Hugo Blunch, October 2006

0612 Unemployment Insurance in Chile: A New Model of Income Support for Unemployed Workers by Germán Acevedo, Patricio Eskenazi and Carmen Pagés, October 2006

0611 Evaluating Social Fund Impact: A Toolkit for Task Teams and Social Fund Managers

by Sarah Adam, October 2006

0610 Risk and Vulnerability Considerations in Poverty Analysis: Recent Advances and Future Directions by Carlo Cafiero and Renos Vakis, October 2006

0609 Comparing Individual Retirement Accounts in Asia: Singapore, Thailand, Hong Kong and PRC by Yasue Pai, September 2006 (online only) 
$0608 \quad$ Pension System Reforms by Anita M. Schwarz, September 2006 (online only)

0607 Youth Labor Market in Burkina Faso: Recent Trends by Daniel Parent, July 2006

0606 Youth in the Labor Market and the Transition from School to Work in Tanzania by Florence Kondylis and Marco Manacorda, July 2006

0605 Redistributing Income to the Poor and the Rich: Public Transfers in Latin America and the Caribbean

by Kathy Lindert, Emmanuel Skoufias and Joseph Shapiro, August 2006 (online only)

0604 Uninsured Risk and Asset Protection: Can Conditional Cash Transfer Programs Serve as Safety Nets?

by Alain de Janvry, Elisabeth Sadoulet, Pantelis Solomon and Renos Vakis, June 2006

0603 Examining Conditional Cash Transfer Programs: A Role for Increased Social Inclusion?

by Bénédicte de la Brière and Laura B. Rawlings, June 2006 (online only)

0602 Civil-service Pension Schemes Around the World

by Robert Palacios and Edward Whitehouse, May 2006 (online only)

0601 Social Pensions Part I: Their Role in the Overall Pension System by Robert Palacios and Oleksiy Sluchynsky, May 2006 (online only)

To view Social Protection Discussion papers published prior to 2006, please visit www.worldbank.org/sp. 


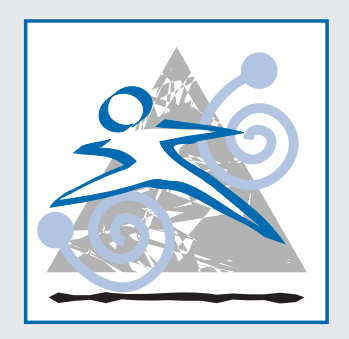

This paper describes the recent reforms of pension policies adopted by Argentina and Chile. The structural reforms in the 1980 s and 90 s were targeted on improving the long term fiscal sustainability of the system and their institutional design, while transferring part of the economic and social risks from the State to participants. However, in recent years authorities in both countries coincided on identifying insufficient coverage among the elderly and adequacy of benefits as the most critical problems. As a result of differences in political economy and institutional constraints, responses were different. In Chile, a long and participatory process resulted in a large reform that focuses on impacts on the medium term, through a carefully calibrated adjustment. In Argentina, instead, reforms were adopted through a large number of successive normative corrections, with little public debate about their implications, and immediate impacts on coverage and fiscal demands.

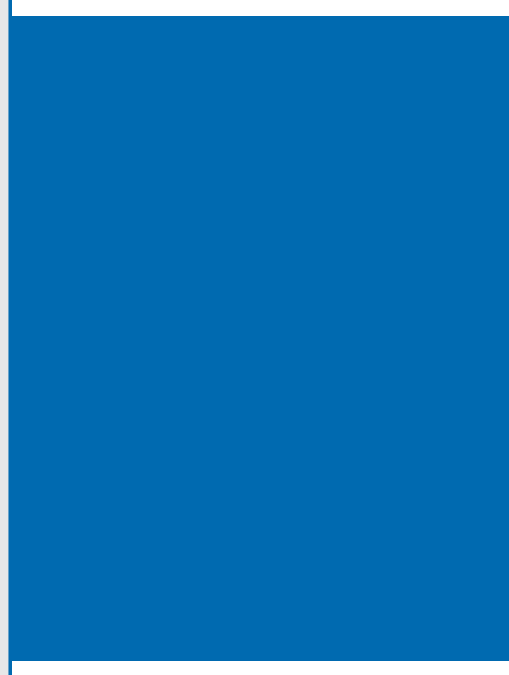

\section{HUMAN DEVEOPMENT NETWORK}

\section{About this series...}

Social Protection Discussion Papers are published to communicate the results of The World Bank's work to the development community with the least possible delay. The typescript manuscript of this paper therefore has not been prepared in accordance with the procedures appropriate to formally edited texts. The findings, interpretations, and conclusions expressed herein are those of the author(s), and do not necessarily reflect the views of the International Bank for Reconstruction and D evelopment /The World Bank and its affiliated organizations, or those of the Executive Directors of The W orld Bank or the governments they represent. The World Bank does not guarantee the accuracy of the data included in this work. For free copies of this paper, please contact the Social Protection Advisory Service, The World Bank, 1818 H Street, N.W., Room G7-703, Washington, D.C. 20433-0001. Telephone: (202) 458-5267, Fax: (202) 614-0471, E-mail: social protection@worldbank.org or visit the Social Protection website at www.worldbank.org/sp. 